Check for updates

Cite this: RSC Adv., 2017, 7, 18199

Received 9th February 2017 Accepted 20th March 2017

DOI: 10.1039/c7ra01673e

rsc.li/rsc-advances

\section{Alkaline-promoted Ni based ordered mesoporous catalysts with enhanced low-temperature catalytic activity toward $\mathrm{CO}_{2}$ methanation $\uparrow$}

\author{
Leilei Xu, (D) *a Fagen Wang, (D) ${ }^{\mathrm{b}}$ Mindong Chen, ${ }^{* a}$ Haoming Yang, ${ }^{a}$ Dongyang $\mathrm{Nie}^{a}$ \\ Lu Qi ${ }^{a}$ and Xinbo Lian ${ }^{a}$
}

For $\mathrm{CO}_{2}$ methanation reaction, a $\mathrm{Mg}$ species is often utilized as the alkaline promotor for $\mathrm{Ni}$ based catalysts to enhance the low-temperature catalytic activity. Herein, based on a pioneer ordered mesoporous $\mathrm{NiO}-\mathrm{Al}_{2} \mathrm{O}_{3}$ catalyst, a $\mathrm{Mg}$ alkaline promotor had been incorporated into the ordered mesoporous framework via a one-pot evaporation induced self-assembly (EISA) strategy. As a result, the ordered mesoporous $\mathrm{NiO}-\mathrm{MgO}-\mathrm{Al}_{2} \mathrm{O}_{3}$ composite oxides with $\mathrm{Mg} / \mathrm{Al}$ molar ratios in a wide range $(0-10 \%)$ were successfully fabricated and directly utilized as the catalysts for $\mathrm{CO}_{2}$ methanation reaction. These mesoporous catalysts were carefully characterized by X-ray diffraction, $\mathrm{N}_{2}$ adsorption-desorption, transmission electron microscopy, selected area electron diffraction, energy dispersive spectrometer, $\mathrm{X}$-ray photoelectron spectroscopy, $\mathrm{H}_{2}$ temperature-programmed reduction, and $\mathrm{CO}_{2}$ temperature-programmed desorption measurements. It was found that the ordered mesoporous materials with large specific surface areas $\left(180.8-232.8 \mathrm{~m}^{2} \mathrm{~g}^{-1}\right)$, big pore volumes $(0.37-$ $0.43 \mathrm{~cm}^{3} \mathrm{~g}^{-1}$ ), and narrow pore size distributions (around $9.5 \mathrm{~nm}$ ) could be successfully retained after the calcination at $700{ }^{\circ} \mathrm{C}$. The highly dispersed $\mathrm{Ni}$ species were strongly interacted with the mesoporous framework in the form of $\mathrm{NiAl}_{2} \mathrm{O}_{4}$ spinel. The incorporation of the $\mathrm{Mg}$ progressively increased the surface basicity of these catalysts, which could intensify the chemisorption and activation of $\mathrm{CO}_{2}$ during the $\mathrm{CO}_{2}$ methanation reaction. Therefore, the low-temperature catalytic activity was significantly enhanced. The "volcano-shape curve" relationship between the $\mathrm{Mg} / \mathrm{Al}$ molar ratio and catalytic activity had been interestingly observed, suggesting only appropriate surface basicity could obtain the optimum catalytic activity. Besides, there was no evident deactivation over these mesoporous catalysts after $50 \mathrm{~h}$ long-term stability tests due to the confinement effect of the mesoporous framework. Therefore, the present ordered mesoporous $\mathrm{NiO}-\mathrm{MgO}-\mathrm{Al}_{2} \mathrm{O}_{3}$ materials could be considered as a series of potential catalyst candidates for $\mathrm{CO}_{2}$ methanation.

\section{Introduction}

In recent years, the increasing amount of $\mathrm{CO}_{2}$ emission by the combustion of fossil fuels contributes to around $82 \%$ of the greenhouse gases. ${ }^{\mathbf{1 , 2}}$ As a result, the global warming problem gradually becomes a threat to the global climate, which can cause the rise of sea levels, melting in glaciers, and other environmental problems. ${ }^{3-5}$ Meanwhile, $\mathrm{CO}_{2}$ is also considered as a raw material for many chemical processes due to its

${ }^{a}$ Collaborative Innovation Center of the Atmospheric Environment and Equipment Technology, School of Environmental Science and Engineering, Nanjing University of Information Science \& Technology, Jiangsu Key Laboratory of Atmospheric Environment Monitoring and Pollution Control, 210044, Nanjing, China. E-mail: leileixu88@gmail.com; chenmdnuist@163.com; Tel: +86-25-58731089

${ }^{b}$ School of Chemistry and Chemical Engineering, Jiangsu University, 301 Xuefu Road, Zhenjiang 212013, P. R. China

$\dagger$ Electronic supplementary information (ESI) available. See DOI: 10.1039/c7ra01673e available, renewable, and nontoxic features. ${ }^{6-8}$ The conversion of $\mathrm{CO}_{2}$ into useful low-carbon fuels (such as methanol, dimethyl ether, methane, etc.) via hydrogenation processes are the main approaches for its large-scale resource utilization. ${ }^{2}$ Although methanol and dimethyl ether are promising fuels, the production of them from $\mathrm{CO}_{2}$ hydrogenation often demands high reaction pressure around $5 \mathrm{MPa} .{ }^{9}$ Besides, the $\mathrm{CO}_{2}$ conversions of these processes are also relatively low $(<20 \%)$ and it is still difficult to realize the complete conversion of $\mathrm{CO}_{2} \cdot{ }^{10}$ Compared with these processes, the $\mathrm{CO}_{2}$ hydrogenation to methane (also called Sabatier reaction) possesses following advantages. The synthetic natural gas $\left(\mathrm{SNG}, \mathrm{CH}_{4}\right)$ can be directly injected and transported by the existing pipeline system. ${ }^{\mathbf{1 1 - 1 3}}$ Furthermore, this reaction can be carried out under atmospheric pressure and the production of $\mathrm{CH}_{4}$ is favorable at low temperature according to its thermodynamic feature. ${ }^{2,7,14}$ Furthermore, it also has potential industrial application prospect once the hydrogen can be derived from the sustainable sources, such as 
biomass, photocatalytic water splitting, etc. ${ }^{2}$ The NASA is also greatly interested with this reaction in view of the future manned space colonization on Mars. ${ }^{7,15}$ The $\mathrm{CO}_{2}$ (95\%) atmosphere of Mars together with the hydrogen from the earth can be converted into methane and water via this process, providing the fuel and life-support system for the astronauts., ${ }^{2,7}$ Therefore, $\mathrm{CO}_{2}$ methanation has recently been received more and more attention.

The metals from group VIII, such as $\mathrm{Ru}, \mathrm{Rh}, \mathrm{Pd}, \mathrm{Ni}$, and $\mathrm{Co}$, are effective catalysts for $\mathrm{CO}_{2}$ methanation based on previous literatures. ${ }^{16-23}$ Among them, the Ni based catalysts are of great interest and have been extensively investigated due to their low cost and facile availability. ${ }^{24-27}$ However, compared with noble metal catalysts, the $\mathrm{Ni}$ based catalysts display poorer catalytic activity, especially at low reaction temperature. Although the low temperature is beneficial to the achievement of high $\mathrm{CO}_{2}$ conversion and $\mathrm{CH}_{4}$ selectivity according to thermodynamic calculation, the full reduction of $\mathrm{CO}_{2}$ into $\mathrm{CH}_{4}$ is still difficult at low temperature over $\mathrm{Ni}$ based catalysts. Because this reaction is an eight-electron process with significant kinetic barrier. ${ }^{7,28}$ In order to obtain acceptable $\mathrm{CO}_{2}$ conversion rate, the catalyst is usually required to decrease the activation energy. Therefore, the development of $\mathrm{Ni}$ based catalysts with advanced lowtemperature catalytic activity remains a great challenge.

Extensive studies have revealed that the low-temperature catalytic performances of $\mathrm{Ni}$ based catalysts are greatly dependent on various influencing parameters, such as the catalytic support, promotor, and preparation method. ${ }^{2,7,28}$ Specifically, the catalytic support has a significant effect on the high dispersion of the metallic active sites, which greatly contributes to the activation and dissociation of the $\mathrm{H}_{2}$ molecule. ${ }^{18,29}$ Thus, the materials with large surface areas, big pore volumes, and unblocked pore channels, such as mesoporous zeolite and mesoporous metal oxides, have been investigated as the supports of the $\mathrm{CO}_{2}$ methanation catalysts. ${ }^{23,30-32}$ As for the $\mathrm{CO}_{2}$, it is an extremely stable molecule with eight out-layer electron structure. In order to decrease its activation energy, the alkaline promotors, such as $\mathrm{MgO}, \mathrm{CaO}, \mathrm{La}_{2} \mathrm{O}_{3}$, and so on, are often used to intensify the surface basicity, which will intensify the chemisorption and activation of the $\mathrm{CO}_{2} \cdot{ }^{33-35}$ As a result, the catalytic activity at low reaction temperature will be promoted.

For Ni based catalyst, another disadvantage is the thermal sintering of the metallic active sites during the processes of reduction and $\mathrm{CO}_{2}$ methanation reaction due to its low Tammann temperature $\left(590{ }^{\circ} \mathrm{C}\right)$, above which the thermal sintering of metallic Ni will easily take place. ${ }^{36}$ Besides, there are possible hot spots existing among the catalyst bed due to exothermic feature of the $\mathrm{CO}_{2}$ methanation reaction. ${ }^{37,38}$ Thus, the temperature of the catalyst bed is usually higher than the reactor temperature. This will aggravate the thermal agglomeration of the metallic Ni active sites and decrease the stability of the catalysts. In order to address this challenge, the $\mathrm{Ni}$ catalytic sites are often stabilized by well-defined crystalline structures (e.g. solid solution, spinel, perovskite, etc.),$^{39-41}$ rigid mesoporous frameworks (e.g. Ni-MCM-41, NiO- $\mathrm{Al}_{2} \mathrm{O}_{3}$, etc.), ${ }^{30,31}$ and core-shell structures (e.g. Ni@SiO ${ }_{2}$ ), ${ }^{42}$ especially for high temperature reactions (such as dry reforming and steam reforming). With the aid of these strategies, the metallic $\mathrm{Ni}$ active sites can be firmly confined and its thermal sintering can be effectively controlled. Among these materials, the catalysts with mesoporous structures can be considered as promising candidates due to their outstanding structural properties, which can expose sufficient active sites for the reactants. For example, Haller et al. reported that the Ni-MCM-41 displayed outstanding catalytic performance comparable to the best results of $\mathrm{Ru} / \mathrm{SiO}_{2}$ noble catalysts toward $\mathrm{CO}_{2}$ methanation owing to its excellent sintering-resistance and textual properties. ${ }^{30}$ Following this guideline, we had successfully synthesized ordered mesoporous $\mathrm{NiO}-\mathrm{Al}_{2} \mathrm{O}_{3}$ composite oxide for $\mathrm{CO}_{2}$ methanation, which displayed much better catalytic performance than both $\mathrm{Ni} / \mathrm{Al}_{2} \mathrm{O}_{3}$ supported and non-porous NiO$\mathrm{Al}_{2} \mathrm{O}_{3}$ catalysts. ${ }^{31}$ However, the low-temperature catalytic activity over ordered mesoporous $\mathrm{NiO}-\mathrm{Al}_{2} \mathrm{O}_{3}$ catalysts still requires further improvement.

Herein, a series of ordered mesoporous NiO-MgO- $\mathrm{Al}_{2} \mathrm{O}_{3}$ materials with different $\mathrm{Mg}$ contents were fabricated by one-pot evaporation-induced self-assembly (EISA) method and directly employed as the catalysts for $\mathrm{CO}_{2}$ methanation reaction. Similar to the ordered mesoporous $\mathrm{NiO}-\mathrm{Al}_{2} \mathrm{O}_{3}$ catalyst, the present materials with wide $\mathrm{Mg} / \mathrm{Al}$ molar ratio (0-10\%) also possessed outstanding textural properties and the $\mathrm{Ni}$ active sites were firmly confined by the mesoporous matrix, promising excellent catalytic activities and stabilities. Besides, the incorporation of the $\mathrm{Mg}$ greatly promoted the surface basicity, which could further intensify the chemisorption of the $\mathrm{CO}_{2}$. The influence the $\mathrm{Mg}$ promotor on the catalytic activity had been carefully investigated. It was found that the presence of the $\mathrm{Mg}$ greatly favored the promotion of low-temperature catalytic activity and only appropriate $\mathrm{Mg}$ content could maximally promote the activity. The relationship between the structure and performance over these catalysts had been elaborated with the aid of the various analyzing techniques.

\section{Experimental}

\subsection{The fabrication of the ordered mesoporous NiO-MgO- $\mathrm{Al}_{2} \mathrm{O}_{3}$ composite metal oxide catalysts}

The ordered mesoporous $\mathrm{NiO}-\mathrm{MgO}-\mathrm{Al}_{2} \mathrm{O}_{3}$ composite metal oxides with different $\mathrm{Mg}$ contents were synthesized by one-pot evaporation induced self-assembly (EISA) strategy, which had been reported elsewhere. ${ }^{43-45}$ In these materials, the Ni/Al molar ratio was controlled at $10 \%$ and the $\mathrm{Mg} / \mathrm{Al}$ molar ratios were controlled at $x \%(x=0,1,3,5,8$, and 10), respectively. Specifically, $1.0 \mathrm{~g}(\mathrm{EO})_{20}(\mathrm{PO})_{70}(\mathrm{EO})_{20}$ (Pluronic P123, $\mathrm{Mn}=5800$, Sigma-Aldrich) structure directing agent was dissolved in 20.0 $\mathrm{mL}$ absolute ethanol with vigorous agitation. $1.6 \mathrm{~mL} 67.0 \mathrm{wt} \%$ nitric acid, $10 \mathrm{mmol}$ aluminum isopropoxide (>98\%, SigmaAldrich), $1 \mathrm{mmol} \mathrm{Ni}\left(\mathrm{NO}_{3}\right)_{2} \cdot 6 \mathrm{H}_{2} \mathrm{O}$ (Sigma-Aldrich), and quantitative $\mathrm{Mg}\left(\mathrm{NO}_{3}\right)_{2} \cdot 6 \mathrm{H}_{2} \mathrm{O}$ (Sigma-Aldrich) were added to above solution in sequence. After $5 \mathrm{~h}$ vigorous agitation, the final transparent light green solution was transferred into a Petri dish, which was put into a convection oven with appropriate temperature $\left(60{ }^{\circ} \mathrm{C}\right)$ and relative humidity $(<50 \%)$ to carry out the EISA process for $48 \mathrm{~h}$. The final light green xerogel was 
calcined at $700{ }^{\circ} \mathrm{C}$ for $5 \mathrm{~h}$ with a ramping heat rate of $1{ }^{\circ} \mathrm{C}$ $\mathrm{min}^{-1}$. For convenience, these ordered mesoporous NiO-MgO$\mathrm{Al}_{2} \mathrm{O}_{3}$ materials with different $\mathrm{Mg}$ contents were abbreviated as OMA-10NixMg, where "OMA", "10", an " $x$ " referred to the "ordered mesoporous alumina matrix", "Ni/Al molar ratio", and "Mg/Al molar ratio", respectively.

The $\mathrm{Ni} / \gamma-\mathrm{Al}_{2} \mathrm{O}_{3}$ supported catalyst was prepared via incipient wetness impregnation method using $\mathrm{Ni}\left(\mathrm{NO}_{3}\right)_{2} \cdot 6 \mathrm{H}_{2} \mathrm{O}$ (SigmaAldrich) as the precursor and investigated as the reference catalyst, which had identical Ni/Al molar ratio $(10 \%)$ to the OMA-10Nix $\mathrm{Mg}$ materials. The catalyst calcined at $700{ }^{\circ} \mathrm{C}$ was denoted as $10 \mathrm{Ni} / \mathrm{Al}_{2} \mathrm{O}_{3}$, where " 10 " stood for the "Ni/Al molar ratio".

\subsection{Catalyst characterizations}

Small-angle and wide-angle X-ray diffraction (XRD) patterns were recorded on the X'pert Pro multipurpose diffractometer (PANalytical, Inc.) with Ni-filtered $\mathrm{Cu} \mathrm{K \alpha}$ radiation (0.15046). The $\mathrm{N}_{2}$ adsorption and desorption analyses were conducted by using a NOVA 2200e (Quantachrome) at liquid nitrogen temperature $\left(-196{ }^{\circ} \mathrm{C}\right)$. Prior to the regular analysis, the sample should be degassed at $200{ }^{\circ} \mathrm{C}$ under vacuum condition for $4 \mathrm{~h}$ to remove physisorbed water and surface impurities. The inductive coupled plasma atomic emission spectrometer (ICP-AES) was determined on the Optima 7300DV (Perkin Elmer) to obtain the actual $\mathrm{Ni} / \mathrm{Al}$ and $\mathrm{Mg} / \mathrm{Al}$ ratios. Transmission electron microscopy (TEM), selected area electron diffraction (SAED), and energy-dispersive spectroscopy (EDS) characterization were carried out on a JEOL 2010F microscope using $200 \mathrm{kV}$ as the working voltage. The powder of the sample ought to be highly dispersed in ethanol with the aid of ultrasonic apparatus before dropping onto the carbon-coated copper grid. X-ray photoelectron spectroscopy (XPS) analyses of the catalysts were recorded over a VG ESCALAB 210 (Thermo Scientific) spectrometer. The binding energy of the C $1 \mathrm{~s}(284.8 \mathrm{eV})$ was used as the standard reference of the XPS data. For XPS analysis, the sample should be loaded on a sample holder coated with conductive adhesive tape and pretreated in high vacuum environment. The $\mathrm{H}_{2}$ temperature programmed reduction $\left(\mathrm{H}_{2}\right.$-TPR $)$ measurements of the catalysts were performed on a Quantachrome ChemBET Pulsar TPR/TPD apparatus. Specifically, $0.1 \mathrm{~g}$ sample was loaded on the U-type quartz tube connected with the equipment. Prior to the formal test, the sample should be purged with He stream (30 $\mathrm{mL} \mathrm{min}^{-1}$ ) at $300{ }^{\circ} \mathrm{C}$ for $1 \mathrm{~h}$ to remove the physicaladsorption water and other surface impurities. Then, the $\mathrm{H}_{2}$ TPR measurement was carried out in 5 vol\% $\mathrm{H}_{2}-95$ vol\% $\mathrm{He}$ stream $\left(80 \mathrm{~mL} \mathrm{~min}{ }^{-1}\right)$ with a $10{ }^{\circ} \mathrm{C}$ min heating rate up to $1100{ }^{\circ} \mathrm{C}$ and the amount of hydrogen consumption was recorded by TCD detector. The $\mathrm{CO}_{2}$ temperature programmed desorption ( $\mathrm{CO}_{2}$-TPD) measurements of the catalysts were carried out on the Micromeritics AutoChem II 2920 Chemisorption analyzer. In particular, $0.1 \mathrm{~g}$ sample loaded in the Utype tube was pretreated at $300{ }^{\circ} \mathrm{C}$ in $\mathrm{He}$ stream for $1 \mathrm{~h}$ to remove the surface impurities. After cooled down to the $25{ }^{\circ} \mathrm{C}$, the sample was exposed to pure $\mathrm{CO}_{2}$ atmosphere $\left(50 \mathrm{~mL} \mathrm{~min}{ }^{-1}\right)$ for $1 \mathrm{~h}$ to make the sample surface saturated with chemisorbed
$\mathrm{CO}_{2}$. Then, the gas was changed into the He stream $(50 \mathrm{~mL}$ $\min ^{-1}$ ) to purge the physically absorbed $\mathrm{CO}_{2}$ until the baseline was stable. Finally, the $\mathrm{CO}_{2}$-TPD was conducted with a heating rate of $20{ }^{\circ} \mathrm{C} \min ^{-1}$ to $900{ }^{\circ} \mathrm{C}$ and the desorbed $\mathrm{CO}_{2}$ signal was also recorded by the TCD detector.

\subsection{Catalyst evaluation}

The $\mathrm{CO}_{2}$ methanation reaction was carried out in a continuousflow fixed-bed tubular quartz reactor (i.d. $=10 \mathrm{~mm}$ ). The reaction temperature was determined and controlled by a coaxial thermocouple located at the center of the catalyst bed. The flow rates of the reactant gases were regulated by calibrated mass flow controllers. Before the catalytic reaction, the catalyst ought to be pre-reduced under $\mathrm{H}_{2} / \mathrm{N}_{2}\left(10 / 20 \mathrm{~mL} \mathrm{~min}{ }^{-1}\right)$ mixed flow at $800{ }^{\circ} \mathrm{C}$ for $2 \mathrm{~h}$ with the ramping heating rate of $1.5^{\circ} \mathrm{C} \mathrm{min}^{-1}$. After purging the reactor with $\mathrm{N}_{2}$ to remove chemisorbed $\mathrm{H}_{2}$, the mixture of the $\mathrm{H}_{2}$ and $\mathrm{CO}_{2}\left(\right.$ molar ratio $\left.\mathrm{H}_{2} / \mathrm{CO}_{2}=4\right)$ without any dilution was introduced into the reactor at a gas hourly space velocity (GHSV) of $15000 \mathrm{~mL}\left(\mathrm{~g}^{-1} \mathrm{~h}^{-1}\right)$. For each catalyst, the catalytic performance was investigated from 200 to $450{ }^{\circ} \mathrm{C}$ at the interval of $50{ }^{\circ} \mathrm{C}$. Lab-scale stability tests were conducted at $400{ }^{\circ} \mathrm{C}$ with the GHSV of $15000 \mathrm{~mL}\left(\mathrm{~g}^{-1} \mathrm{~h}^{-1}\right)$ for $50 \mathrm{~h}$ under atmospheric pressure. Before flowing into the on-line GC system, the product gases effluent from the reactor was mixed with the $\mathrm{N}_{2}$ (5 $\left.\mathrm{mL} \mathrm{min}^{-1}\right)$ as an internal standard gas. Finally, the mixture of product gases were injected on line via the automatic six-port valve injectors and subsequently analyzed by the GC machine (Agilent 7890B) equipped with a packed column (TDX-01) for TCD and an alumina capillary column for FID. However, there was no $\mathrm{C} 2+$ hydrocarbon detected by the FID detector. Therefore, the $\mathrm{CO}_{2}$ conversion (abbreviated as $C_{\mathrm{CO}_{2}}$ ) and $\mathrm{CH}_{4}$ selectivity (denoted as $S_{\mathrm{CH}_{4}}$ ) were calculated based on the following formulas.

$$
\begin{gathered}
C_{\mathrm{CO}_{2}}=\left(F_{\mathrm{CO}_{2}, \text { inlet }}-F_{\mathrm{CO}_{2}, \text { outlet }}\right) / F_{\mathrm{CO}_{2}, \text { inlet }} \times 100 \% \\
S_{\mathrm{CH}_{4}}=F_{\mathrm{CH}_{4} \text {, outlet }} /\left(F_{\mathrm{CH}_{4} \text {,outlet }}-F_{\mathrm{CO}, \text { outlet }}\right) \times 100 \%
\end{gathered}
$$

In all formulas, the $F_{x \text {,inlet }}$ and $F_{x \text {,outlet }}$ represented the flow rate of the $x$ species, which flowed into and out of the reactor, respectively.

\section{Results and discussion}

\subsection{Physical and chemical properties of the fresh catalysts}

The small-angle $\left(0.5-5^{\circ}\right)$ and wide-angle $\left(20-80^{\circ}\right)$ XRD patterns of the fresh OMA-10Nix Mg catalysts were displayed in Fig. 1(1) and (2), respectively. It could be observed in Fig. 1(1) that all the OMA-10Nix $\mathrm{Mg}$ catalysts with different $\mathrm{Mg}$ contents exhibited two groups of peaks in the range of $0.76-0.78^{\circ}$ and $1.30-1.50^{\circ}$, which could be attributed to the $\left(\begin{array}{lll}1 & 0 & 0\end{array}\right)$ and $\left(\begin{array}{lll}1 & 1 & 0\end{array}\right)$ directed inflections, respectively. This suggested the presence of two dimensional p6mm hexagonal ordered mesoporous channel with long-range orderliness. Besides, the incorporation of the $\mathrm{Mg}$ species almost had no obviously adverse effect on the

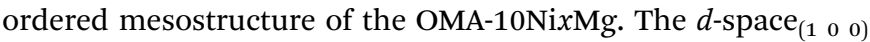
values of these samples were calculated based on the peak 
position of the $\left(\begin{array}{lll}1 & 0 & 0\end{array}\right)$ directed reflection according to Bragg's equation. As observed in the Table 1, their values were in the range of 11.3-11.9 $\mathrm{nm}$, which belonged to mesopore (2-50 nm) based on the IUPAC definition. ${ }^{46}$ As for the wide-angle XRD patterns in Fig. 1(2), all the OMA-10NixMg samples with identical Ni loading amount did not display any diffraction peaks related with $\mathrm{Ni}$ species, such as $\mathrm{NiO}, \mathrm{NiAl}_{2} \mathrm{O}_{4}$, and so on, suggesting the high dispersion of Ni species among the ordered mesoporous framework. However, the diffraction peak of $\mathrm{MgAl}_{2} \mathrm{O}_{4}$ spinel phase (PDF-\#-21-1152) gradually appeared and became stronger and stronger with the increase of $\mathrm{Mg} / \mathrm{Al}$ molar ratio from $0 \%$ to $10 \%$. In contrast, the XRD pattern of the conventional $10 \mathrm{Ni} / \mathrm{Al}_{2} \mathrm{O}_{3}$ supported catalyst in Fig. S1 (ESI $\dagger$ ) displayed apparent NiO (PDF-\#-44-1159) diffraction peak, suggesting its relatively poorer $\mathrm{Ni}$ dispersion than OMA-10Nix Mg counterparts.

The $\mathrm{N}_{2}$ adsorption-desorption isotherms and corresponding pore size distribution curves of the OMA- $10 \mathrm{Ni} x \mathrm{Mg}$ materials were presented in Fig. 1(3) and (4). As shown in Fig. 1(3), all the materials possessed IV type isotherms with steep H1 shaped hysteresis loops in the range of $0.5-0.9 P / P_{0}$ owing to the capillary condensation of $\mathrm{N}_{2}$ among the mesoporous channels, suggesting the presence of mesoporous channels with cylindrical shapes. ${ }^{45}$ Besides, the Fig. 1(4) described the corresponding pore size distribution curves of these materials, which were calculated according to the Barrett-Joyner-Halenda (BJH) method using the adsorption branch. It could be observed that all the OMA-10NixMg materials regardless of the Mg contents displayed greatly narrow pore size distributions around $9.5 \mathrm{~nm}$. As a comparison, the fresh $10 \mathrm{Ni} / \mathrm{Al}_{2} \mathrm{O}_{3}$ catalyst in Fig. S2 (ESI $\dagger$ ) displayed IV $\mathrm{H} 2$ shaped isotherm and narrow pore size distribution around $6.0 \mathrm{~nm}$. This suggested the presence of the mesoporous structure, which was mainly originated from the $\gamma$ $\mathrm{Al}_{2} \mathrm{O}_{3}$ support, not from the assembly process. Furthermore, the textural properties, such as Brunauer-Emmett-Teller (BET) specific surface areas, pore volumes, BJH pore diameters, and wall thickness of the mesopores, were summarized in Table 1. It was noticeable that all the OMA-10Nix Mg materials were still provided with large surface areas up to $232.8 \mathrm{~m}^{2} \mathrm{~g}^{-1}$ and pore volumes up to $0.43 \mathrm{~cm}^{3} \mathrm{~g}^{-1}$ after calcination at $700{ }^{\circ} \mathrm{C}$, which were somewhat better than $10 \mathrm{Ni} / \mathrm{Al}_{2} \mathrm{O}_{3}$ supported catalyst. The wall thicknesses of these samples were in the range of 3.4$4.2 \mathrm{~nm}$. The influence of the $\mathrm{Mg}$ modification on the textural properties of OMA-10NixMg was not obvious. Besides, the values of actual $\mathrm{Ni} / \mathrm{Al}$ and $\mathrm{Mg} / \mathrm{Al}$ molar ratios for the fresh OMA$10 \mathrm{Ni} x \mathrm{Mg}$ and $10 \mathrm{Ni} / \mathrm{Al}_{2} \mathrm{O}_{3}$ catalysts based on the ICP-AES measurements were also summarized in Table 1. It was noticeable that the actual values of the $\mathrm{Ni} / \mathrm{Al}$ and $\mathrm{Mg} / \mathrm{Al}$ molar ratios did not deviate too much from their corresponding theoretical values.

The TEM images of the fresh OMA-10NixMg materials were shown in Fig. 2. It could be observed that all the samples exhibited the alignments of cylindrical shaped mesopores along $\left[\begin{array}{lll}1 & 1 & 0\end{array}\right]$ direction (Fig. 2(a-c) and $\left.(\mathrm{e}-\mathrm{g})\right)$ and $\left[\begin{array}{lll}0 & 0 & 1\end{array}\right]$ direction (Fig. 2(d)), which confirmed the presence of $2 \mathrm{D}$ p6mm hexagonally structured mesoporous channels. This was well consistent
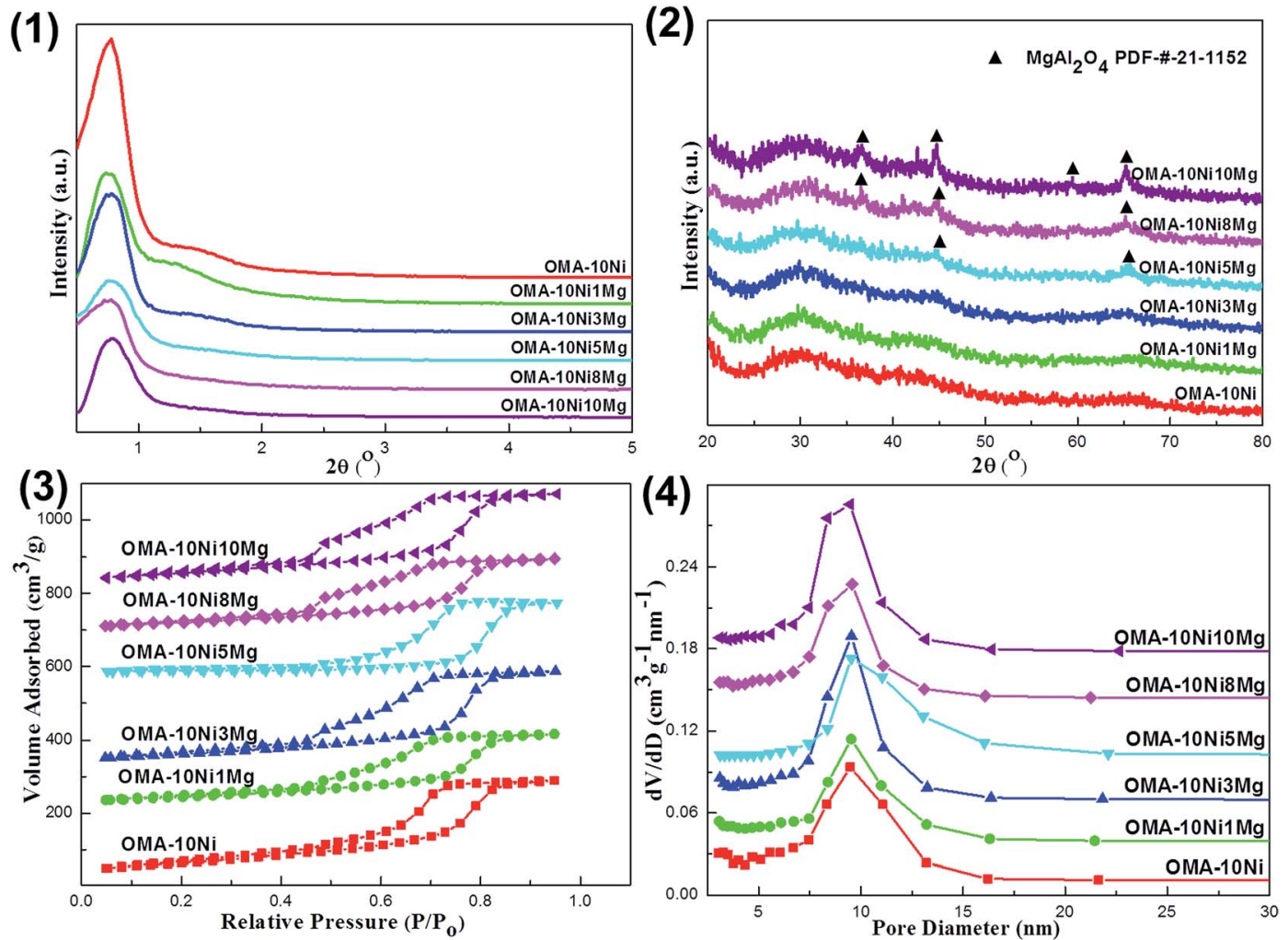

Fig. 1 (1) Small-angle and (2) wide-angle X-ray diffraction patterns of the fresh OMA-10NixMg catalysts; (3) nitrogen adsorption-desorption isotherms and (4) pore size distribution curves of the fresh OMA-10NixMg catalysts. 
Table 1 Textual properties of the fresh and $50 \mathrm{~h}$ spent catalysts based on the XRD, $\mathrm{N}_{2}$ adsorption-desorption, ICP-AES, and kinetic analyses

\begin{tabular}{|c|c|c|c|c|c|c|c|c|c|}
\hline Samples & $\begin{array}{l}S_{\mathrm{BET}}{ }^{a} \\
\left(\mathrm{~m}^{2} \mathrm{~g}^{-1}\right)\end{array}$ & $\begin{array}{l}V_{\mathrm{BJH}}^{b} \\
\left(\mathrm{~cm}^{3} \mathrm{~g}^{-1}\right)\end{array}$ & $\begin{array}{l}\mathrm{APD}^{c} \\
(\mathrm{~nm})\end{array}$ & $\begin{array}{l}d_{(100)}{ }^{e} \\
(\mathrm{~nm})\end{array}$ & $\begin{array}{l}\mathrm{WT}^{f} \\
(\mathrm{~nm})\end{array}$ & $\mathrm{Ni} / \mathrm{Al}^{g}$ & $\mathrm{Mg} / \mathrm{Al}^{g}$ & $\begin{array}{c}E_{\mathrm{a}}{ }^{h} \\
\left(\mathrm{~kJ} \mathrm{~mol}^{-1}\right)\end{array}$ & $\begin{array}{l}\text { Isotherm } \\
\text { type }\end{array}$ \\
\hline OMA-10Ni & 232.8 & 0.42 & 9.5 & 11.3 & 3.5 & 0.097 & - & 75.2 & IV H1 \\
\hline OMA-10Ni3Mg & 180.8 & 0.43 & 9.5 & 11.3 & 3.4 & 0.095 & 0.032 & 63.6 & IV H1 \\
\hline OMA-10Ni5Mg & 188.7 & 0.37 & 9.5 & 11.6 & 3.9 & 0.097 & 0.053 & 57.6 & IV H1 \\
\hline OMA-10Ni8Mg & 187.6 & 0.39 & 9.6 & 11.3 & 3.4 & 0.094 & 0.078 & 65.5 & IV H1 \\
\hline SP-OMA-10Ni & 139.0 & 0.27 & 8.5 & - & - & 0.098 & - & - & IV H1 \\
\hline $\mathrm{SP}^{d}$-OMA-10Ni3Mg & 138.4 & 0.31 & 8.3 & - & - & 0.093 & 0.034 & - & IV H1 \\
\hline SP-OMA-10Ni5Mg & 135.9 & 0.32 & 8.4 & - & - & 0.095 & 0.049 & - & IV H1 \\
\hline $\mathrm{SP}-10 \mathrm{Ni} / \mathrm{Al}_{2} \mathrm{O}_{3}$ & 107.0 & 0.11 & 5.0 & & & 0.096 & - & - & IV H2 \\
\hline
\end{tabular}

${ }^{a} S_{\mathrm{BET}}$ stands for the specific area calculated based on Brunauer-Emmett-Teller theory. ${ }^{b} V_{\mathrm{BJH}}$ stands for the pore volume calculated based on Barrett-Joyner-Halenda theory. ${ }^{c}$ APD stands for average pore diameter. ${ }^{d}$ SP stands for $100 \mathrm{~h}$ spent catalyst. ${ }^{e} d_{(100)}$ stands for the $d$-spacing of the $\left(\begin{array}{lll}1 & 0 & 0\end{array}\right)$ direction calculated by the Bragg's law: $d=n \lambda / 2 \sin \theta$, where $\lambda$ is the wavelength of the X-ray wave $(0.15406 \mathrm{~nm}) .{ }^{f}$ WT stands for the wall thickness (calculated by $2 \times d_{(100)} / \sqrt{3}$ - pore diameter). ${ }^{g} \mathrm{Ni} / \mathrm{Al}$ and $\mathrm{Mg} / \mathrm{Al}$ molar ratios were obtained by ICP-AES analyses. ${ }^{h} E_{\mathrm{a}}$ stood for the apparent activation energy of $\mathrm{CO}_{2}$.

with the deduction based on the small-angle XRD and $\mathrm{N}_{2}$ adsorption-desorption analyses. Similar to wide-angle XRD, the selected area electron diffraction (SAED) could also provide information related with the crystallinity of the materials. As displayed in the insets of Fig. $2(\mathrm{a}-\mathrm{c})$ and $(\mathrm{e}-\mathrm{g})$, the diffraction rings of these samples were not very distinguishable, implying the poor crystallinity of the mesoporous framework. Therefore, the results of XRD and SAED were in good agreement with each other. Furthermore, the EDS characterization was conducted over OMA-10Ni10Mg and its profile was displayed in Fig. 2(h). The characteristic peaks of $\mathrm{Ni}, \mathrm{Mg}, \mathrm{Al}, \mathrm{O}, \mathrm{C}$, and $\mathrm{Cu}$ elements could be identified in the EDS profile. For the $\mathrm{C}$ and $\mathrm{Cu}$ peaks, they ought to be derived from the copper grid coated with carbon film. The co-presence of $\mathrm{Ni}, \mathrm{Mg}$, Al, O peaks suggested that these elements had been successfully introduced into ordered mesoporous OMA-10Ni10Mg material.

The interaction strength between the $\mathrm{Ni}$ species and the ordered mesoporous $\mathrm{Al}_{2} \mathrm{O}_{3}$ matrix was investigated by the $\mathrm{H}_{2}-$ TPR over the OMA-10NixMg catalysts with different $\mathrm{Mg}$ contents. Their profiles were displayed in Fig. 3(1). It was worth noting that each sample only possessed one pronounced $\mathrm{H}_{2}$ reduction peak around $820.0^{\circ} \mathrm{C}$ in the whole temperature range investigated $\left(100-1070{ }^{\circ} \mathrm{C}\right)$. This suggested that the strong metal-framework interaction had been formed. The absence of the reduction peak in low temperature region $\left(300-500{ }^{\circ} \mathrm{C}\right)$ demonstrated that there was no disassociated NiO species weakly bonded with mesoporous framework. ${ }^{47}$ The reason for this phenomenon could be attributed to the unique "one-pot" fabrication strategy. Different with the conventional supported catalysts, the $\mathrm{Ni}$ active sites were in situ introduced into the ordered mesoporous framework during the one-pot EISA process. It was supposed that the location of the Ni species was homogenously embedded among the ordered mesoporous $\mathrm{Al}_{2} \mathrm{O}_{3}$ matrix owing to the advantage of the "one-pot" synthesis strategy. As a result, there was almost no big difference between the "surface" and "bulk" Ni species in their chemical coordination environment, accounting for the only one evident reduction peak for each OMA-10NixMg sample. However, the $\mathrm{H}_{2}$-TPR profile of $\mathrm{Ni} / \mathrm{Al}_{2} \mathrm{O}_{3}$ supported catalyst in Fig. S3(1) (ESI $\dagger$ ) exhibited two pronounced peaks centered at $517.6{ }^{\circ} \mathrm{C}$ and $891.9^{\circ} \mathrm{C}$, which could be identified as the $\mathrm{NiO}$ species with weak and strong interactions with the $\gamma-\mathrm{Al}_{2} \mathrm{O}_{3}$ support, respectively. This result suggested that the $\mathrm{Ni}$ species was heterogeneously distributed over the surface of $\mathrm{Al}_{2} \mathrm{O}_{3}$ support after impregnation process. Therefore, compared with OMA- $10 \mathrm{Ni} x \mathrm{Mg}$, it was relatively easier to reduce the weakly interacted $\mathrm{Ni}$ species over $\mathrm{Ni} /$ $\mathrm{Al}_{2} \mathrm{O}_{3}$ catalyst, which was well consistent with the previous reports. ${ }^{31,47,48}$ Thus, the metallic Ni active sites in OMA-10NixMg would be endowed with enhanced anti-sintering performance.

Fig. 3(2) showed the XPS profiles of Ni 2p for the fresh OMA$10 \mathrm{Nix} \mathrm{Mg}$ materials with different $\mathrm{Mg}$ contents. It was of great interest to find that all the samples irrespective of the amount $\mathrm{Mg}$ contents displayed identical Ni $2 \mathrm{p}$ profiles in the shape. Specifically, each sample exhibited one main $\mathrm{Ni} 2 \mathrm{p}_{3 / 2}$ peak around $856.0 \mathrm{eV}$ and another satellite peak around $862.0 \mathrm{eV}$, which were the featured peaks $\mathrm{Ni}^{2+}$ in the form of $\mathrm{NiAl}_{2} \mathrm{O}_{4}$ spinel species. ${ }^{49}$ This indicated that the $\mathrm{NiAl}_{2} \mathrm{O}_{4}$ species existed over the surface of the OMA-10NixMg catalysts and the incorporation of the $\mathrm{Mg}$ alkaline promotor into the mesoporous framework did not influence the chemical coordination environment of the Ni elements. For OMA-10NixMg catalysts, the Ni species were homogenously distributed among the whole materials due to the advantage of "one-pot" strategy. There ought to be no difference between the bulk and surface Ni species. Thus, it can be supposed that the $\mathrm{Ni}$ species embedded in the inner part of the mesoporous framework was also in the form of $\mathrm{NiAl}_{2} \mathrm{O}_{4}$ phase. Actually, the single-reduction peak over these OMA10Nix Mg materials in Fig. 3(1) had already demonstrated the presence of the $\mathrm{NiAl}_{2} \mathrm{O}_{4}$ species, which only could be reduced at high temperature above $800{ }^{\circ} \mathrm{C}$. Therefore, the absence of $\mathrm{NiAl}_{2} \mathrm{O}_{4}$ diffraction peak in Fig. 1(2) was because of the high dispersion of the $\mathrm{NiAl}_{2} \mathrm{O}_{4}$ among the amorphous $\mathrm{Al}_{2} \mathrm{O}_{3}$ framework. As for $\mathrm{Ni} / \mathrm{Al}_{2} \mathrm{O}_{3}$ supported catalyst, its $\mathrm{Ni} 2 \mathrm{p}$ XPS profile in Fig. S3(2) (ESI $\dagger$ ) displayed the $2 \mathrm{p}_{3 / 2}$ peak at $855.8 \mathrm{eV}$, which was 


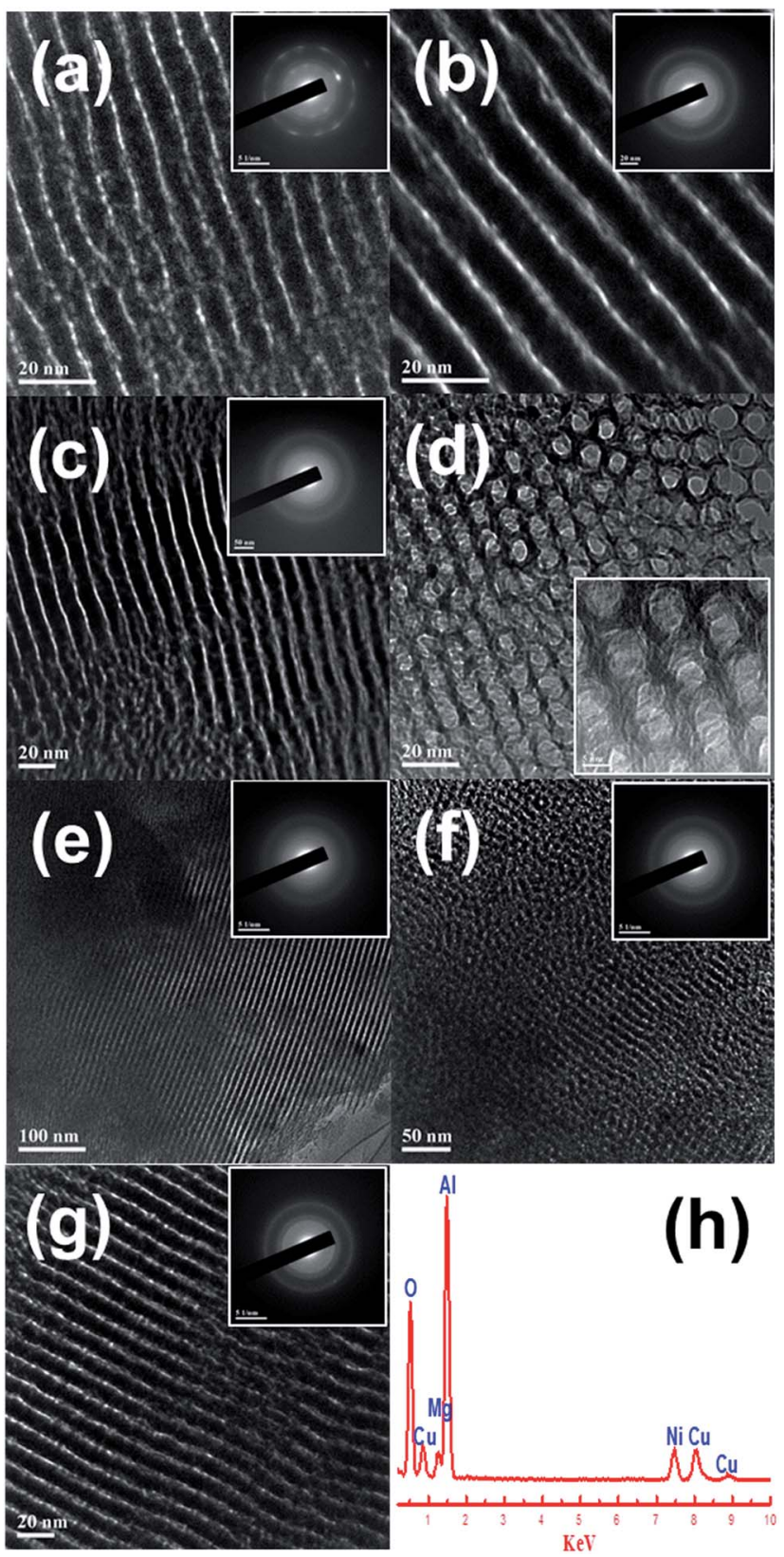

Fig. 2 TEM, SAED, and EDS measurements of the fresh OMA-10NixMg catalysts: (a) OMA-10Ni, (b) OMA-10Ni1Mg, (c and d) OMA-10Ni3Mg; (e) OMA-10Ni5Mg; (f) OMA-10Ni8Mg; ( $g$ and h) OMA-10Ni10Mg.

a bit lower than peak position of $\mathrm{Ni} 2 \mathrm{p}_{3 / 2}$ in OMA-10NixMg. The shift toward to the lower binding energy region ought to be attributable to the surface NiO species, which could be reduced at low temperature according to $\mathrm{H}_{2}$-TPR analysis in Fig. S3(1). $\dagger$

The $\mathrm{CO}_{2}$-TPD measurements had been carried out over the fresh OMA-10NixMg materials to investigate the surface basicity, which would greatly affect the chemisorption and activation of the $\mathrm{CO}_{2}$ during the catalytic reaction. Their $\mathrm{CO}_{2}$-TPD profiles were displayed in the Fig. 4. For all the samples, their desorption peaks of $\mathrm{CO}_{2}$ were very similar in the shapes, which were mainly centered at 83.2 and $460.5{ }^{\circ} \mathrm{C}$. The first peak at $83.2^{\circ} \mathrm{C}$ might be attributed to the weakly chemisorbed $\mathrm{CO}_{2}$ molecules, which

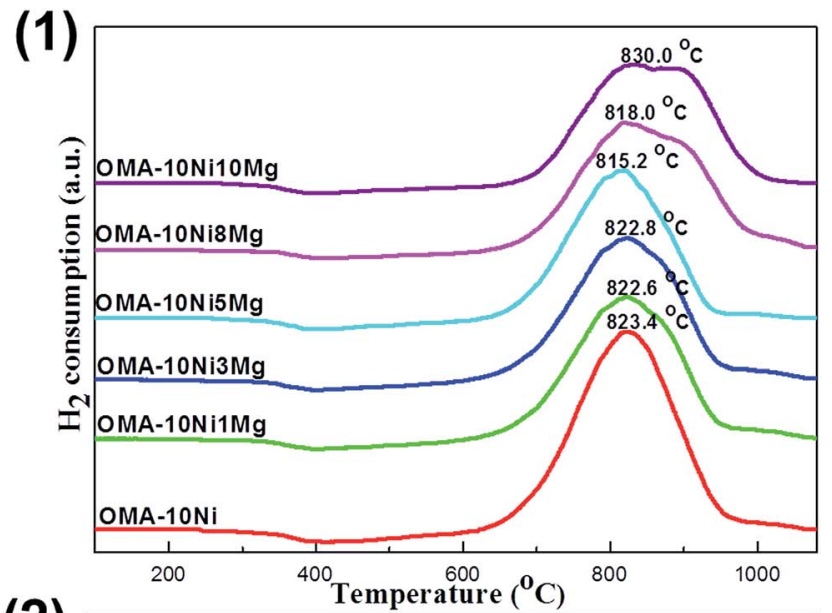

(2)

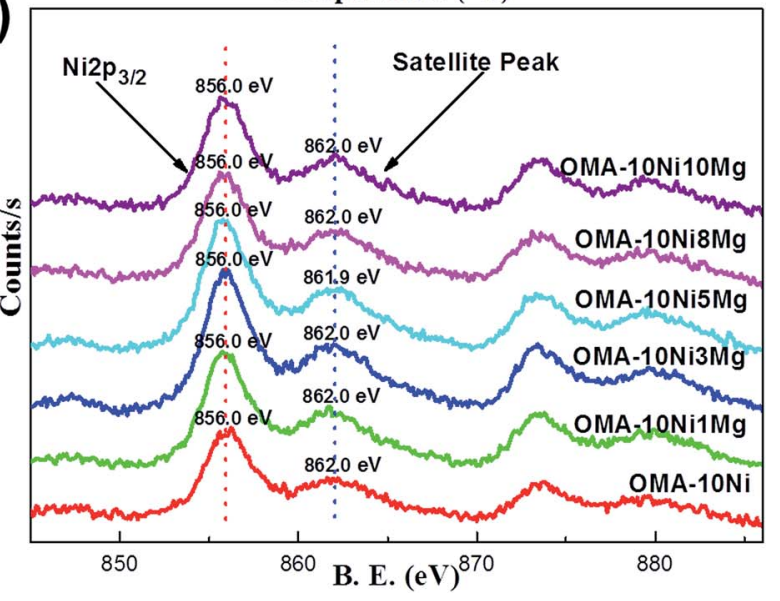

Fig. 3 (1) $\mathrm{H}_{2}$-TPR and (2) Ni 2p XPS profiles of the fresh OMA-10NixMg catalysts.

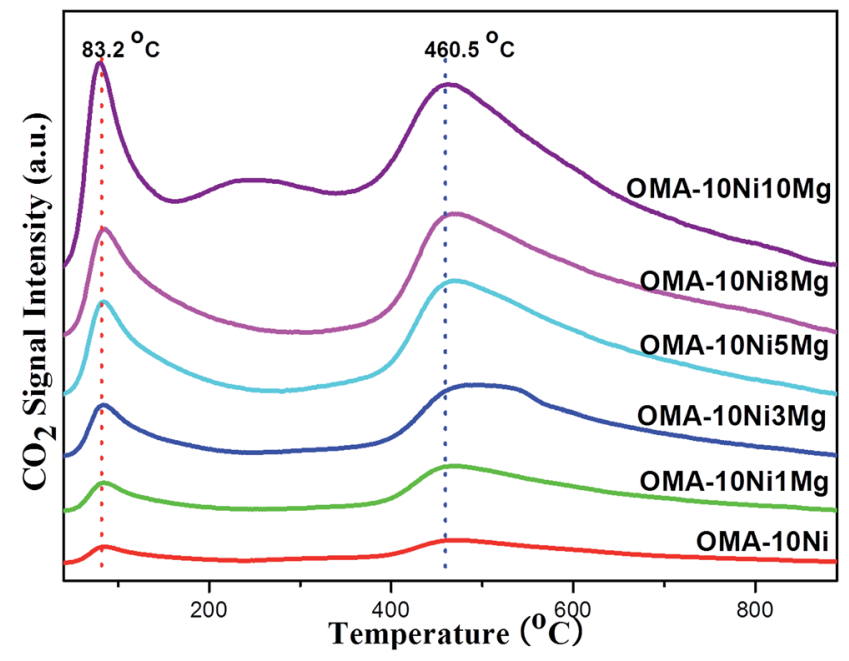

Fig. $4 \mathrm{CO}_{2}$-TPD profiles of the fresh OMA-10NixMg catalysts.

possibly interacted with the surface basic sites in the form of monodentate carbonate species. ${ }^{50,51}$ The second peak at $460.5^{\circ} \mathrm{C}$ ought to be derived from the decomposition of bidentate and/or polydentate carbonates, which strongly interacted with the basic 
sites. ${ }^{\mathbf{5 0 , 5 1}}$ Besides, it could be noticeable that the intensity of the $\mathrm{CO}_{2}$ desorption peak was greatly related with the $\mathrm{Mg}$ contents, which was in agreement with previous reports. ${ }^{52,53}$ Specifically, with the increase of $\mathrm{Mg} / \mathrm{Al}$ molar ratio from $0 \%$ to $10 \%$, the surface basicity progressively increased and the formation of $\mathrm{MgAl}_{2} \mathrm{O}_{4}$ phase did not influence the total surface basicity. In summary, the incorporation $\mathrm{Mg}$ species into the mesoporous framework could simultaneously promote the weak basic site and strong basic site, which would be favorable in subsequent processes of $\mathrm{CO}_{2}$ chemisorption and activation during $\mathrm{CO}_{2}$ methanation reaction.

\subsection{Catalytic performances for $\mathrm{CO}_{2}$ methanation}

Prior to the regular catalyst evaluation, the blank test was conducted without loading catalysts. Almost no catalytic activity was detected in the temperature range of $200-450{ }^{\circ} \mathrm{C}$, demonstrating the critical role of catalyst in promoting catalytic activity. For the catalytic activity tests, the data related with $\mathrm{CO}_{2}$ conversion and $\mathrm{CH}_{4}$ selectivity was the average values of three times.

The effect of the $\mathrm{Mg}$ basic modifier on the catalytic activities at different reaction temperatures had been investigated over OMA-10Nix Mg catalysts under specified conditions $\left(\mathrm{H}_{2} / \mathrm{CH}_{4}=\right.$ $\left.4, \mathrm{GHSV}=15000 \mathrm{~mL}\left(\mathrm{~g}^{-1} \mathrm{~h}^{-1}\right), 1 \mathrm{~atm}\right)$. The curves of the $\mathrm{CO}_{2}$ conversion versus $\mathrm{Mg} / \mathrm{Al}$ molar ratio at different reaction temperatures were described in Fig. 5. It was noticeable that these curves at different temperatures were similar to "volcanoshape curve" in the shape, which was very universal in the catalysis field..$^{5,55}$ Specifically, with the increase of $\mathrm{Mg} / \mathrm{Al}$ molar ratio from $0 \%$ to $5 \%$, the $\mathrm{CO}_{2}$ conversion continuously increased until reaching the maximum value; however, further increasing the $\mathrm{Mg} / \mathrm{Al}$ molar ratio up to $10 \%$ would cause the decline of the $\mathrm{CO}_{2}$ conversion. This suggested that only appropriate amount of $\mathrm{Mg}$ basic modifier could maximally promote the catalytic activity, which was well consistent with pioneer report. ${ }^{34}$ According to the above $\mathrm{CO}_{2}$-TPD analysis, the presence

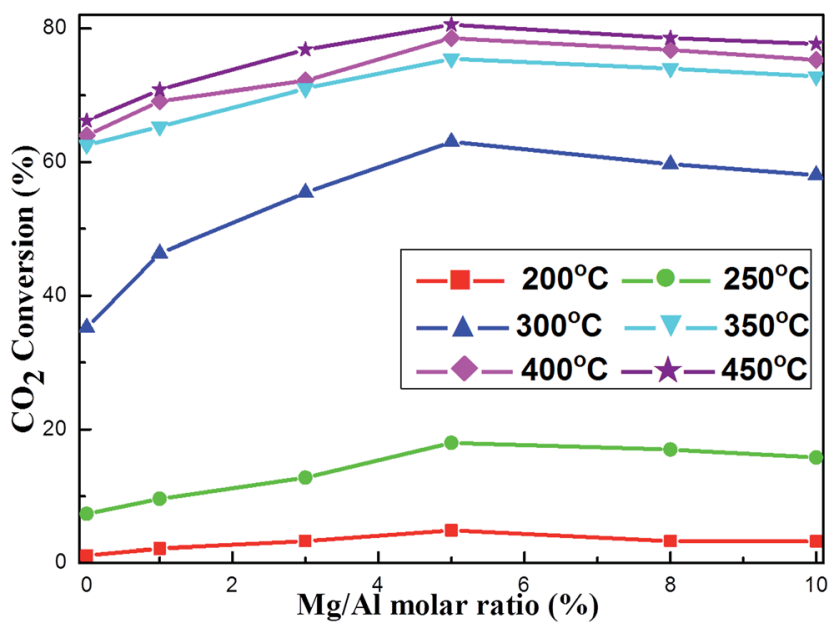

Fig. 5 The curve of the $\mathrm{CO}_{2}$ conversion versus $\mathrm{Mg} / \mathrm{Al}$ molar ratio at different reaction temperatures over the OMA-10NixMg catalysts; reaction condition: $\mathrm{H}_{2} / \mathrm{CO}_{2}=4, \mathrm{GHSV}=15000 \mathrm{~mL} \mathrm{~g}^{-1} \mathrm{~h}^{-1}, 1 \mathrm{~atm}$. of $\mathrm{Mg}$ evidently increased the surface basicity, which was proportional to the amount of $\mathrm{Mg}$ species. This could greatly intensify the chemisorption and subsequent activation of $\mathrm{CO}_{2}$ during the reaction, which could finally decrease the activation energy of $\mathrm{CO}_{2}$. As a result, the catalytic activity of the alkaline modified catalyst, especially at low reaction temperature could be promoted. However, excessive $\mathrm{Mg}$ basic promotor would firmly absorb the $\mathrm{CO}_{2}$ and the subsequent desorption step of $\mathrm{CO}_{2}$ would become difficult, which might cause the coverage of neighboring $\mathrm{Ni}$ active sites and the blockage of following activation of $\mathrm{H}_{2}$. Consequently, the $\mathrm{CO}_{2}$ conversion suffered some decline because of the excessive surface basicity. Therefore, only $\mathrm{Mg} / \mathrm{Al}$ molar ratio (5\%) could evidently promote the catalytic activity to the utmost.

The role of $\mathrm{Mg}$ alkaline promotor in enhancing the catalytic activity over OMA-10Ni $x \mathrm{Mg}$ catalysts toward $\mathrm{CO}_{2}$ methanation, especially at low temperature, was further confirmed by the kinetic study. The Arrhennius plots of the OMA-10NixMg catalysts with different $\mathrm{Mg} / \mathrm{Al}$ molar ratios were displayed in Fig. S4 $(\mathrm{ESI} \dagger)$ and their corresponding apparent activation energies of $\mathrm{CO}_{2}$ were summarized in Table 1. It was of great interest to find that the catalysts with basic modification displayed much lower apparent activation energies of $\mathrm{CO}_{2}$ than pristine OMA-10Ni catalyst without any modification. The results suggested that the incorporation of the $\mathrm{Mg}$ alkaline promotor possessed positive roles in $\mathrm{CO}_{2}$ activation. Specifically, with the increase of $\mathrm{Mg} / \mathrm{Al}$ molar ratio from $0 \%$ to $5 \%$, the $\mathrm{CO}_{2}$ activation energy gradually decreased from $75.2 \mathrm{~kJ} \mathrm{~mol}^{-1}$ to $57.6 \mathrm{~kJ} \mathrm{~mol}^{-1}$. However, further increasing the $\mathrm{Mg} / \mathrm{Al}$ molar ratio up to $10 \%$ caused the increase of the $\mathrm{CO}_{2}$ activation energy. This indicated that only appropriate $\mathrm{Mg} / \mathrm{Al}$ molar ratio (5\%) could achieve the lowest activation energy of the $\mathrm{CO}_{2}$ because of "volcano-shape curve" phenomenon.

The influence of reaction temperature on the catalytic activity and selectivity was studied over OMA-10Ni, OMA$10 \mathrm{Ni} 5 \mathrm{Mg}$, and $10 \mathrm{Ni} / \mathrm{Al}_{2} \mathrm{O}_{3}$ representative catalysts in the region of $200-450{ }^{\circ} \mathrm{C}$. As observed in Fig. 6(1), the $\mathrm{CO}_{2}$ conversions over most of these catalysts gradually increased with the increase of the reaction temperature from 200 to $400{ }^{\circ} \mathrm{C}$ and achieved the maximum values at $400{ }^{\circ} \mathrm{C}$; however, the further increase of the temperature to $450{ }^{\circ} \mathrm{C}$ caused the decline of the $\mathrm{CO}_{2}$ conversion. Actually, the trends of these three curves were completely different with that of the theoretical equilibrium $\mathrm{CO}_{2}$ conversion curve, which gradually decreased with the increase of the reaction temperature. ${ }^{28}$ Although the low reaction temperature was favorable for the high $\mathrm{CO}_{2}$ conversion, the kinetic limitation for $\mathrm{CO}_{2}$ activation was a great barrier for the achievement of outstanding low-temperature activity. ${ }^{7}$ In order to overcome this difficulty, the alkaline promotor was used for intensifying the processes of chemisorption and activation. Therefore, compared with the OMA-10Ni, the OMA-10Ni5Mg behaved much higher $\mathrm{CO}_{2}$ conversion, which was more close to the theoretical equilibrium conversion. Furthermore, it was also noticeable to find that the $\mathrm{CO}_{2}$ conversions over both OMA$10 \mathrm{Ni}$ and OMA-10Ni5Mg catalysts were also much higher than that over $10 \mathrm{Ni} / \mathrm{Al}_{2} \mathrm{O}_{3}$ catalyst, especially in the low temperature region. This could be attributed to the better textural properties 

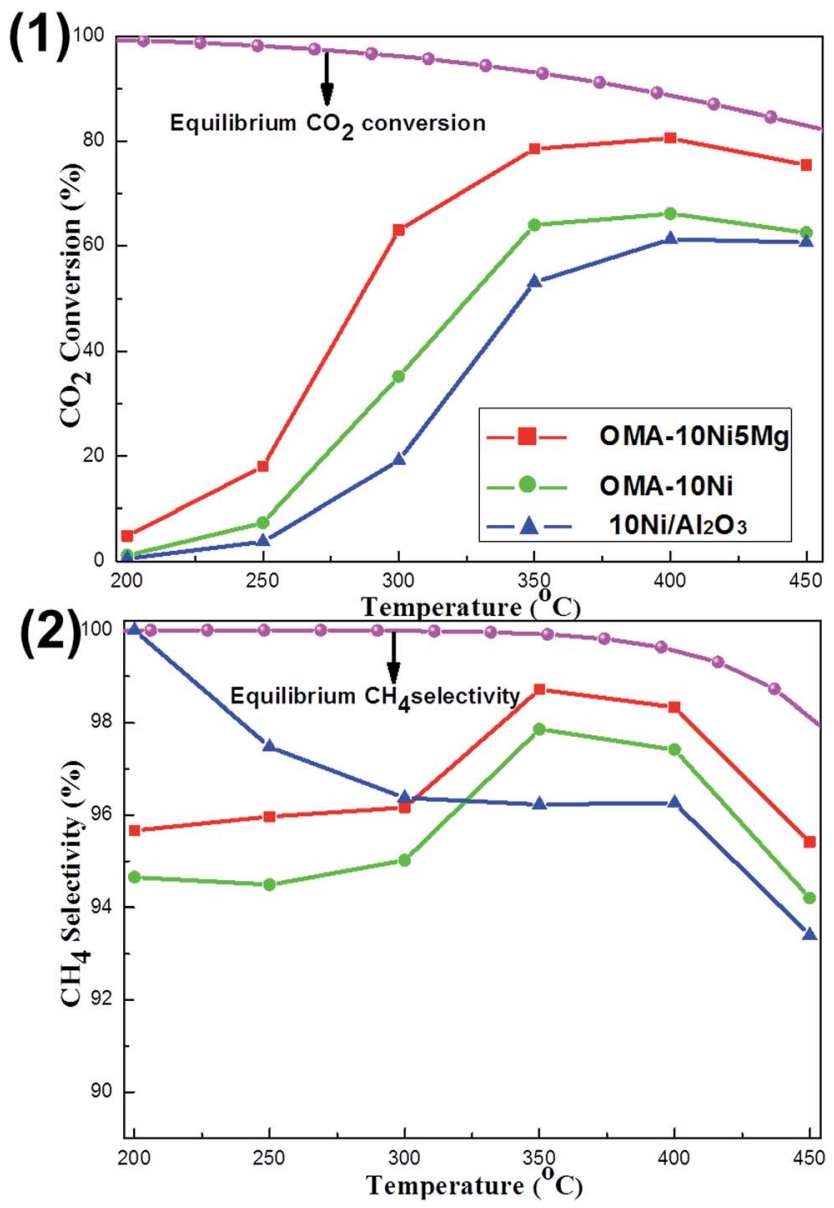

Fig. 6 The curves of the (1) $\mathrm{CO}_{2}$ conversion and (2) $\mathrm{CH}_{4}$ selectivity versus reaction temperature over OMA-10 NixMg and $10 \mathrm{Ni} / \mathrm{Al}_{2} \mathrm{O}_{3}$ catalysts; reaction condition: $\mathrm{H}_{2} / \mathrm{CO}_{2}=4, \mathrm{GHSV}=15000 \mathrm{~mL} \mathrm{~g}^{-1} \mathrm{~h}^{-1}$, $1 \mathrm{~atm}$.

of the ordered mesoporous catalysts, such as larger surface area and unimpeded mesoporous channel, which made the mass diffusion of the gaseous reactants toward metallic Ni active sites become easier. This accounted for the lower $\mathrm{CO}_{2}$ activation energies over OMA-10Nix Mg catalysts than $10 \mathrm{Ni} / \mathrm{Al}_{2} \mathrm{O}_{3}$ catalyst (77.1 $\mathrm{kJ} \mathrm{mol}^{-1}$, see Table 1). Besides, the relationship between the $\mathrm{CH}_{4}$ selectivity and the reaction temperature was reflected in the Fig. 6(2). It could be observed that the equilibrium $\mathrm{CH}_{4}$ selectivity gradually decreased with the increase of the temperature due to the reverse water-gas shift (RWGS) side reaction, which could generate the $\mathrm{CO}$ and decrease the $\mathrm{CH}_{4}$ selectivity. ${ }^{56}$ For the $\mathrm{CH}_{4}$ selectivity over these three real catalysts, their values at different temperatures were lower than the corresponding theoretical equilibrium selectivity. Specifically, the OMA-10Ni and OMA-10Ni5Mg displayed their highest $\mathrm{CH}_{4}$ selectivity at $350{ }^{\circ} \mathrm{C}$ and $10 \mathrm{Ni} / \mathrm{Al}_{2} \mathrm{O}_{3}$ showed its highest $\mathrm{CH}_{4}$ selectivity at $200{ }^{\circ} \mathrm{C}$. Besides, the OMA-10Ni5Mg with basic modification displayed a bit higher $\mathrm{CH}_{4}$ selectivity than the pristine OMA-10Ni. This suggested that the presence of $\mathrm{Mg}$ basic site was beneficial to the enhancement of the $\mathrm{CH}_{4}$ selectivity. For the reaction mechanism of the $\mathrm{CO}_{2}$ methanation, though they had been intensively investigated over different kinds of active sites, the arguments related with the reaction intermediates had not reached a consensus. For the Ni based catalysts, it was reported that the $\mathrm{CO}_{2}$ methanation reaction was initiated by the dissociation of $\mathrm{CO}_{2}$ into a carbon species $\left(\mathrm{CO}_{\mathrm{ads}}\right)$ and an oxygen species $\left(\mathrm{O}_{\text {ads }}\right)$ over the catalyst surface and the $\mathrm{CO}_{\text {ads }}$ subsequently reacted with $\mathrm{H}$ atom to generate $\mathrm{CH}_{4}$ on $\mathrm{Ni}$ active site, which was responsible for dissociating the $\mathrm{H}_{2}$ into $\mathrm{H}$ atom. ${ }^{27,57,58}$ The presence of the $\mathrm{Mg}$ basic modifier might intensify the formation of the $\mathrm{CO}_{\mathrm{ads}}$ species and suppress the desorption process of $\mathrm{CO}_{\text {ads }}$ into $\mathrm{CO}$, which accounted for the relatively higher $\mathrm{CH}_{4}$ selectivity over OMA-10Ni5Mg catalyst. Besides, the $\mathrm{CH}_{4}$ selectivity was also closely related with the state of the metallic $\mathrm{Ni}$ active site. If the thermal sintering of the $\mathrm{Ni}$ active sites took place, the $\mathrm{H}_{2}$ dissociation into $\mathrm{H}_{\text {ads }}$ would be blocked, which would also cause the decrease of the $\mathrm{CH}_{4}$ selectivity due to lack of $\mathrm{H}_{\text {ads }}$ source. Therefore, the lower $\mathrm{CH}_{4}$ selectivity over $10 \mathrm{Ni} / \mathrm{Al}_{2} \mathrm{O}_{3}$ catalyst than the other mesoporous catalysts at high temperature above $300{ }^{\circ} \mathrm{C}$ might be caused by the thermal sintering of the metallic Ni active sites.

The development of the $\mathrm{Ni}$ based catalyst with long-term catalytic stability was also an important concern because the thermal sintering of the $\mathrm{Ni}$ active sites easily took place. Therefore, the $50 \mathrm{~h}$ lab-scale long term stability tests were carried out under given conditions $\left(\mathrm{H}_{2} / \mathrm{CO}_{2}=4,400{ }^{\circ} \mathrm{C}, \mathrm{GHSV}=\right.$ $\left.15000 \mathrm{~mL}\left(\mathrm{~g}^{-1} \mathrm{~h}^{-1}\right), 1 \mathrm{~atm}\right)$. The OMA-10Ni, OMA-10Ni3Mg, OMA-10Ni5Mg, and $10 \mathrm{Ni} / \mathrm{Al}_{2} \mathrm{O}_{3}$ catalysts were chosen as the representatives for the stability tests and their catalytic performances were summarized in Fig. 7. As shown in the Fig. 7(1), there was no obvious deactivation observed over OMA-10Ni, OMA-10Ni3Mg, and OMA-10Ni5Mg mesoporous catalysts after $50 \mathrm{~h}$ stability tests, displaying greatly excellent catalytic stabilities. This suggested that the deactivation caused by the thermal sintering of the Ni active sites had been successfully avoided owing to the confinement effect of the mesoporous framework, which could stabilize the metallic $\mathrm{Ni}$ nanoparticles by the mesoporous framework. In contrast, the $\mathrm{CO}_{2}$ conversion over traditional $10 \mathrm{Ni} / \mathrm{Al}_{2} \mathrm{O}_{3}$ supported catalyst gradually decreased from $61.2 \%$ to $55.3 \%$ during the whole $50 \mathrm{~h}$ stability test, which ought to be caused by the thermal sintering of the metallic $\mathrm{Ni}$ active sites due to weak metal-support interaction. Furthermore, it was noticeable that the $\mathrm{CO}_{2}$ conversions over OMA$10 \mathrm{Ni} 3 \mathrm{Mg}(76.3 \%)$ and OMA-10Ni5Mg $(80.3 \%)$ were still higher than that over OMA-10Ni (67.8\%), once more demonstrating the positive roles of alkaline promotors in enhancing the catalytic activity. Besides, the catalytic performances related with $\mathrm{CH}_{4}$ selectivity were depicted in Fig. $7(2)$. Similar to the $\mathrm{CO}_{2}$ conversions, the corresponding $\mathrm{CH}_{4}$ selectivity over OMA-10Ni, OMA-10Ni3Mg, and OMA-10Ni5Mg catalysts kept stable during the whole $50 \mathrm{~h}$ time on stream. However, the general trend of the $\mathrm{CH}_{4}$ selectivity over $10 \mathrm{Ni} / \mathrm{Al}_{2} \mathrm{O}_{3}$ supported catalyst was descendent because of thermal sintering of the metallic $\mathrm{Ni}$ active sites. As for the $\mathrm{CH}_{4}$ selectivity, it was also very sensitive to the thermal sintering of the metallic active sites based on the previous reports, which were responsible for the dissociation of the $\mathrm{H}_{2}$ into $\mathrm{H}_{\mathrm{ads}} \cdot{ }^{18,31,57}$ The thermal agglomeration of the metallic active sites would cause the deceleration of the $\mathrm{H}_{2}$ 

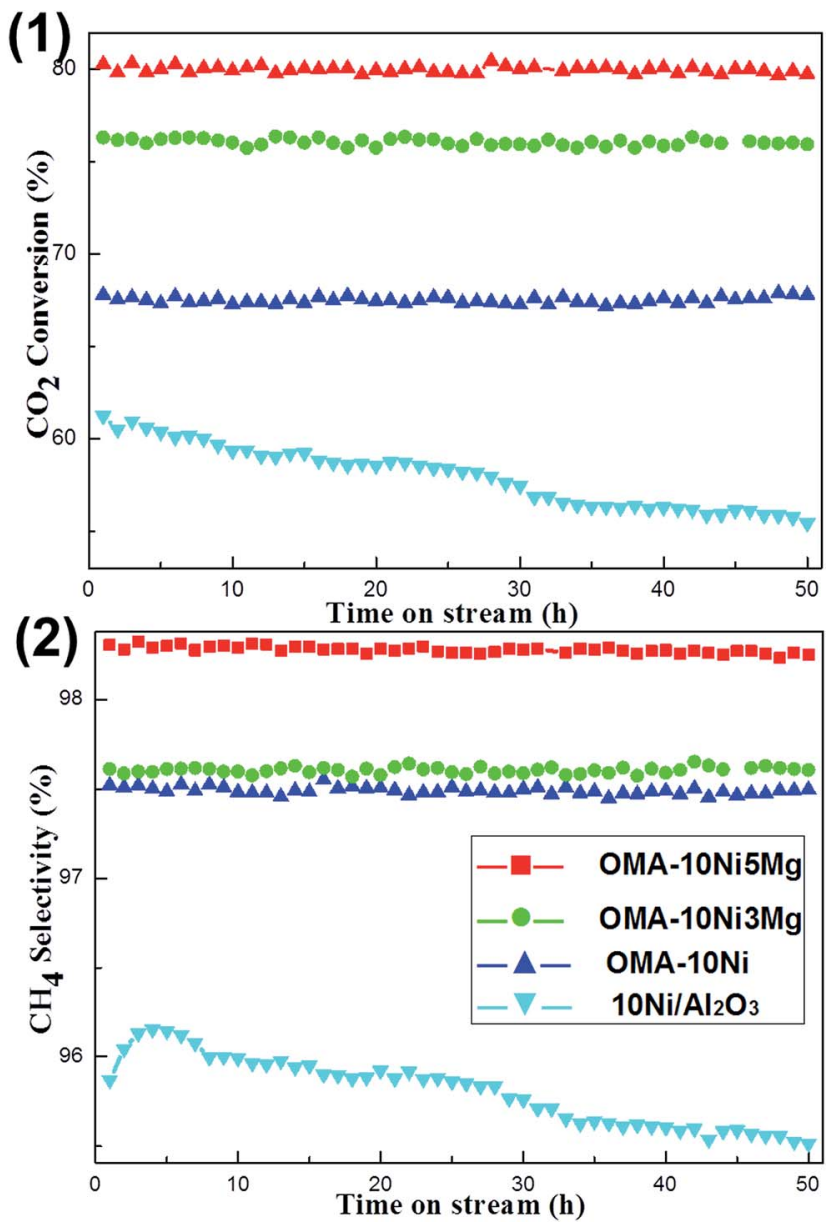

Fig. $750 \mathrm{~h}$ long-term stability tests over OMA-10NixMg and $10 \mathrm{Ni} /$ $\mathrm{Al}_{2} \mathrm{O}_{3}$ catalysts: (1) $\mathrm{CO}_{2}$ conversion and (2) $\mathrm{H}_{2}$ selectivity; reaction conditions: $\mathrm{H}_{2} / \mathrm{CO}_{2}=4, \mathrm{GHSV}=15000 \mathrm{~mL} \mathrm{~g}^{-1} \mathrm{~h}^{-1}, 400{ }^{\circ} \mathrm{C}, 1 \mathrm{~atm}$.

dissociation, finally leading to the decomposition of the $\mathrm{CO}_{\text {ads }}$ into $\mathrm{CO}$ due to the lack of $\mathrm{H}_{\mathrm{ads} .}{ }^{18,31}$ For the current OMA-10NixNi catalysts, the steadiness of their $\mathrm{CH}_{4}$ selectivity during the long-

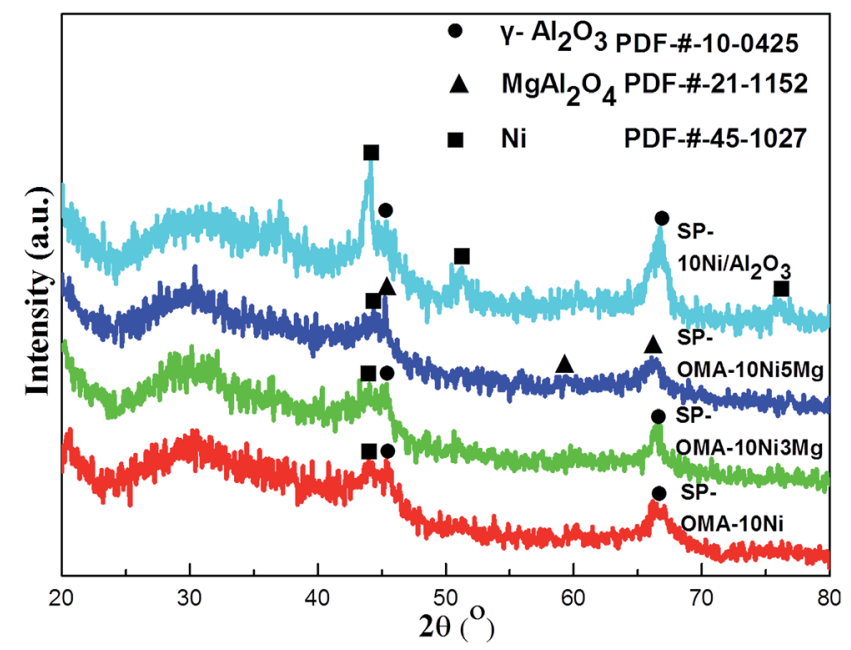

Fig. 8 X-ray diffraction patterns of the $50 \mathrm{~h}$ spent OMA-10NixMg and $10 \mathrm{Ni} / \mathrm{Al}_{2} \mathrm{O}_{3}$ catalysts. term stability tests was attributed to the enhanced thermal stability of the metallic Ni active sites, which were stabilized by the ordered mesoporous $\mathrm{Al}_{2} \mathrm{O}_{3}$ matrix. Therefore, compared with the $10 \mathrm{Ni} / \mathrm{Al}_{2} \mathrm{O}_{3}$ supported catalyst, the OMA-10NixMg catalysts exhibited more excellent catalytic stabilities.

Overall, the low-temperature catalytic activity over OMA10Nix Mg catalysts had been obviously enhanced by the incorporation of $\mathrm{Mg}$ alkaline promotor by intensifying the surface basicity. Compared with conventional $10 \mathrm{Ni} / \mathrm{Al}_{2} \mathrm{O}_{3}$ supported catalyst, these ordered mesoporous catalysts were provided with better structural properties, higher metallic Ni dispersion, and stronger metalsupport interaction, which endowed them with more excellent catalytic performances. However, the obtained $\mathrm{CO}_{2}$ conversions over these OMA-10NixMg catalysts were still much lower than the chemical equilibrium value and had enough room to be improved. As for the Ni-Al based catalysts, except for the current mesoporous catalysts, the Ni-Al hydrotalcite catalysts recently had been extensively investigated for $\mathrm{CO}_{2}$ methanation due to their unique structural properties, where the $\mathrm{Ni}$ active sites could be highly dispersed among the layers of hydrotalcite crystalline structure..$^{58-60}$ Abate et al. reported that the Ni-Al hydrotalcite catalysts $(75-80$ wt\% $\mathrm{NiO}$ ) could approximately approach the equilibrium $\mathrm{CO}_{2}$ conversion at the temperature above $300{ }^{\circ} \mathrm{C}$ with highly diluted feed gases $\left(\mathrm{H}_{2} / \mathrm{CO}_{2} / \mathrm{N}_{2}=10 / 2.5 / 87.5, \mathrm{GHSV}=20000 \mathrm{~h}^{-1}, 5 \mathrm{bar}\right) .^{59}$
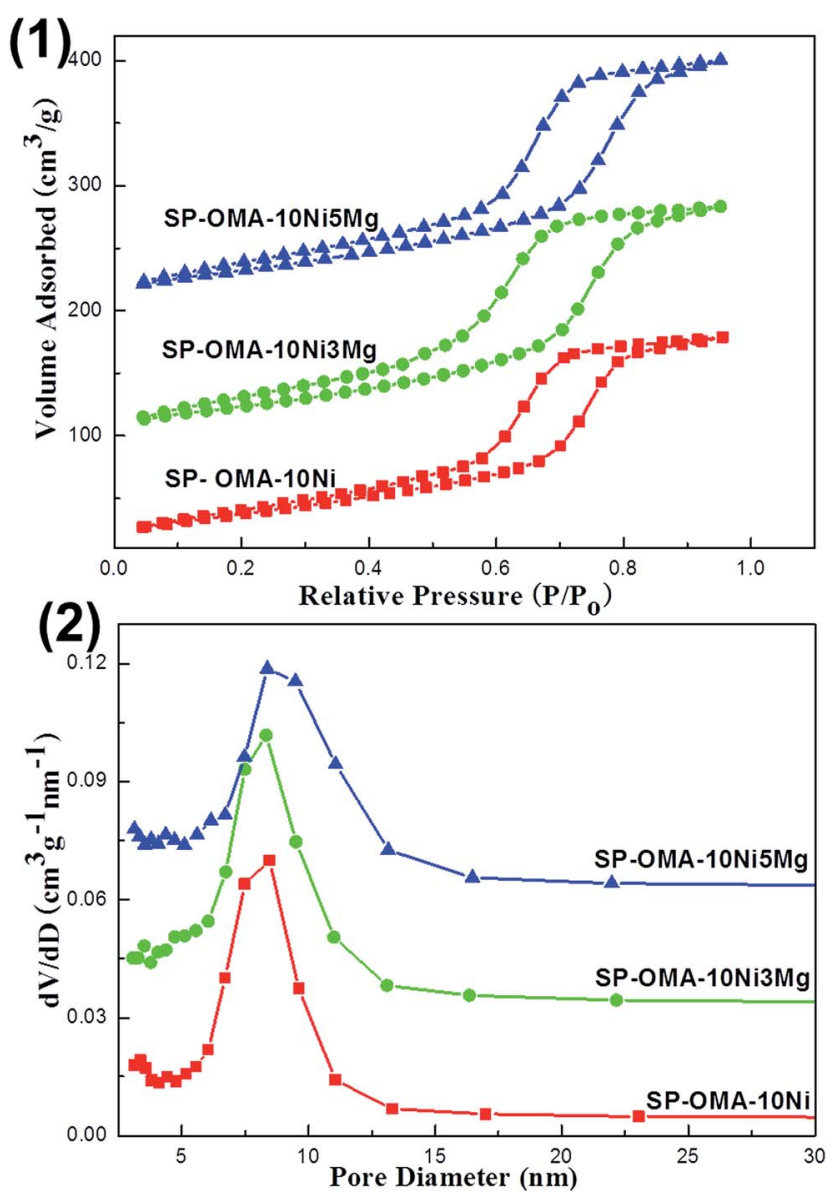

Fig. 9 (1) Nitrogen adsorption-desorption isotherms and (2) pore size distribution curves of the $50 \mathrm{~h}$ spent OMA-10NixMg catalysts. 
Batte et al. reported a series ( $\mathrm{Ni}, \mathrm{Mg}, \mathrm{Al})$-hydrotalcite-like catalysts (59 wt $\% \mathrm{Ni}$ ) for $\mathrm{CO}_{2}$ methanation with diluted feed gases $\left(\mathrm{H}_{2} / \mathrm{CO}_{2} /\right.$ $\left.\mathrm{Ar} / \mathrm{N}_{2}=18.5 / 4.6 / 12.8 / 64.1, \mathrm{WHSV}=1100 \mathrm{~mL}\left(\mathrm{~g}_{\text {cat }} \mathrm{min}\right)^{-1}\right) .{ }^{60}$ The maximum $\mathrm{CO}_{2}$ conversion of $(74 \pm 2) \%$ could be achieved at the temperatures between 330 and $350{ }^{\circ} \mathrm{C}$. Wierzbicki et al. fabricated (Ni, $\mathrm{La}, \mathrm{Mg}, \mathrm{Al}$ )-hydrotalcite derived catalysts (15 wt $\% \mathrm{Ni}$ ) for $\mathrm{CO}_{2}$ methanation with diluted feed gases $\left(\mathrm{H}_{2} / \mathrm{CO}_{2} / \mathrm{Ar}=12 / 3 / 5, \mathrm{GHSV}=\right.$ $\left.12000 \mathrm{~h}^{-1}\right) .{ }^{58}$ The $\mathrm{CO}_{2}$ conversion of $c a .46 .0 \%$ could be obtained over the catalysts with 2 and $4 \mathrm{wt} \% \mathrm{La}$ at $250{ }^{\circ} \mathrm{C}$ owing to the enhancement of medium strength basic sites by La. Apparently, the $\mathrm{Ni}-\mathrm{Al}$ hydrotalcite and ( $\mathrm{Ni}, \mathrm{La}, \mathrm{Mg}, \mathrm{Al})$ catalysts displayed higher $\mathrm{CO}_{2}$ conversions at low temperature than the OMA$10 \mathrm{Nix} \mathrm{Mg}$ catalysts (about $10.0 \mathrm{wt} \% \mathrm{Ni}$ ). However, these catalysts with different metallic Ni loading amounts were investigated under different reaction conditions. Therefore, these results could not be directly comparable with each other. The common advantages of $\mathrm{Ni}-\mathrm{Al}$ hydrotalcite and OMA- $10 \mathrm{Ni} x \mathrm{Mg}$ catalysts were that the $\mathrm{Ni}$ active sites were effectively confined and the sintering of the metallic Ni could be inhibited, which accounted for their good catalytic stabilities. Based on this concept, if the Ni-Al hydrotalcite based ordered mesoporous catalyst could be fabricated, its lowtemperature catalytic activity and stability would be further improved because of their own unique advantages.

\subsection{Characterization of the used catalysts}

The XRD characterizations of the $50 \mathrm{~h}$ spent (denoted as SP) OMA-10Ni, OMA-10Ni3Mg, OMA-10Ni5Mg, and $10 \mathrm{Ni} / \mathrm{Al}_{2} \mathrm{O}_{3}$

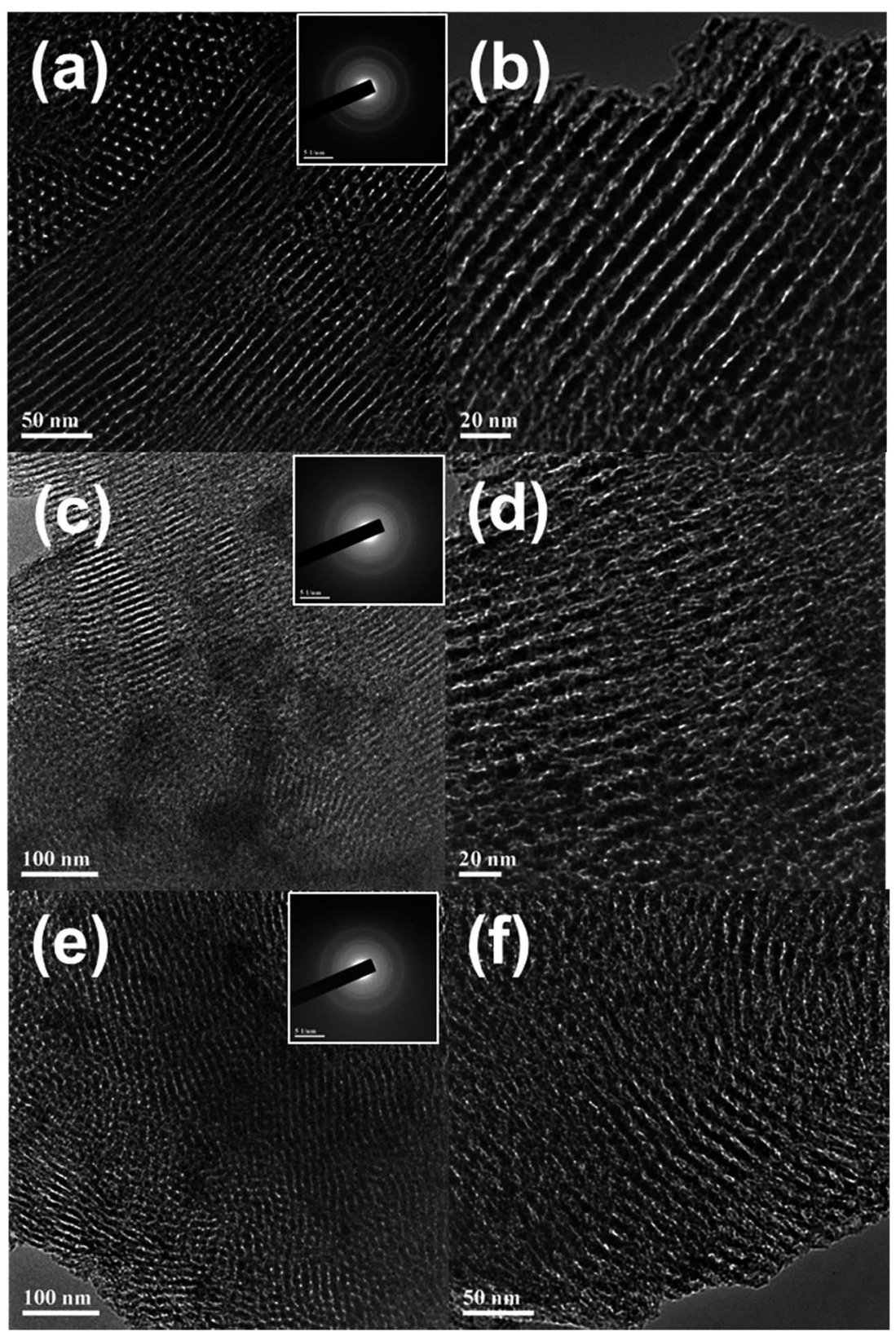

Fig. 10 TEM and SAED images of the $50 \mathrm{~h}$ spent OMA-10NixMg catalysts: (a and b) SP-OMA-10Ni, (c and d) SP-OMA-10Ni3Mg, (e and f) SPOMA-10Ni5Mg. 
catalysts were carried out and their XRD patterns were exhibited in Fig. 8. As observed, the $\mathrm{SP}-10 \mathrm{Ni} / \mathrm{Al}_{2} \mathrm{O}_{3}$ supported catalyst displayed much stronger metallic Ni diffraction peaks than the other SP-OMA-10NixMg catalysts. This illustrated that the OMA$10 \mathrm{Ni} x \mathrm{Mg}$ catalysts possessed much stronger sintering-resistant abilities than the $10 \mathrm{Ni} / \mathrm{Al}_{2} \mathrm{O}_{3}$ supported catalyst owing to the confinement effect of the mesoporous framework. Thus, the metallic Ni active sites among the OMA-10Ni $x \mathrm{Mg}$ catalysts could be effectively stabilized by the mesoporous $\mathrm{Al}_{2} \mathrm{O}_{3}$ matrix, accounting for no deactivation after $50 \mathrm{~h}$ long-term stability tests. Furthermore, the spent OMA-10NixMg catalysts also displayed characteristic diffraction peaks of metallic $\gamma-\mathrm{Al}_{2} \mathrm{O}_{3}$ and/ or $\mathrm{MgAl}_{2} \mathrm{O}_{4}$ phases, which were different with their corresponding fresh samples. The appearance of the $\gamma-\mathrm{Al}_{2} \mathrm{O}_{3}$ and/or $\mathrm{MgAl}_{2} \mathrm{O}_{4}$ diffraction peaks over SP-OMA-10NixMg catalysts might be attributed to the pre-reduction procedure at high temperature $\left(800{ }^{\circ} \mathrm{C}\right)$, which promoted the phase transformation from the amorphous to crystalline $\gamma-\mathrm{Al}_{2} \mathrm{O}_{3}$ and/or $\mathrm{MgAl}_{2} \mathrm{O}_{4}$ phases.

The nitrogen adsorption and desorption analyses were also carried out over the $50 \mathrm{~h}$ spent catalysts and their results were displayed in Fig. 9 and S2 (ESI $\dagger$ ). As can be seen in Fig. 9(1), all the spent OMA-10NixMg catalysts still showed IV isotherms with steep H1-shaped hysteresis loops in the range of $0.5-0.9 P /$ $P_{0}$. This indicated that the ordered cylindrical mesoporous channels had been successfully retained after experiencing the $2 \mathrm{~h}$ high temperature reduction at $800{ }^{\circ} \mathrm{C}$ and $50 \mathrm{~h}$ long-term stability tests at $400{ }^{\circ} \mathrm{C}$. Furthermore, as can be seen in Fig. 9(2), their corresponding pore size distribution curves centered at 8.3-8.5 $\mathrm{nm}$ were very narrow. As for the SP-10Ni/ $\mathrm{Al}_{2} \mathrm{O}_{3}$ catalyst, similar to its fresh precursor, the spent sample also displayed IV-H2 type isotherm and narrow pore size distribution curve in Fig. S2 (ESI $\dagger$ ). Besides, as shown in the Table 1, the values of the specific surface areas and pore volumes of all the spent catalysts also suffered some decline. As for the SP-OMA-10NixMg catalysts, the decline was mainly derived from the thermal shrinkage of the mesoporous framework during the processes of reduction and reaction for these catalysts. But the thermal shrinkage had not cause the deformation and collapse of the ordered mesoporous skeletons according to their IV H1-shaped isotherms and narrow pore size distributions, demonstrating outstanding thermal stability. For the $\mathrm{SP}-10 \mathrm{Ni} / \mathrm{Al}_{2} \mathrm{O}_{3}$ catalyst, the decrease in its surface area and pore volume might be mainly because of the thermal sintering of the metallic Ni, which would cause the blockage of the pore channel by large clusters. In addition, the $\mathrm{Ni} / \mathrm{Al}$ and $\mathrm{Mg} / \mathrm{Al}$ molar ratios (see Table 1) of the spent catalysts were also determined by ICP-AES. The values were comparable to their corresponding fresh catalysts, suggesting that the serious loss of the metallic Ni active sites did not occur.

TEM analyses of the $50 \mathrm{~h}$ spent catalysts were conducted to further investigate the thermal sintering property of the metallic Ni active sites and/or the morphology of the ordered mesoporous channels. As shown in the Fig. 10, the uniformly cylindrical mesopore channels viewed along the $\left[\begin{array}{lll}1 & 1 & 0\end{array}\right]$ direction could be observed over these 50 h SP-OMA-10NixMg catalysts, suggesting that the ordered mesoporous structures had been successfully retained after $50 \mathrm{~h}$ stability tests. Besides, it was worth noting that no obvious metallic Ni cluster could be observed over all the SP-OMA-10NixMg catalysts, demonstrating excellent thermal sintering-resistance property. In sharp contrast, as can be seen in the Fig. S5 (ESI $\dagger$ ), the large metallic $\mathrm{Ni}$ clusters appeared over $\mathrm{SP}-10 \mathrm{Ni} / \mathrm{Al}_{2} \mathrm{O}_{3}$ catalyst. This proved that serious thermal sintering of the metallic Ni active sites had taken place, which had been already confirmed by the XRD characterization in Fig. 8. Therefore, the current OMA-10Ni $x \mathrm{Mg}$ catalysts displayed much better anti-sintering property than $10 \mathrm{Ni} / \mathrm{Al}_{2} \mathrm{O}_{3}$ supported catalyst.

\section{Conclusions}

In summary, a series of ordered mesoporous NiO-MgO- $\mathrm{Al}_{2} \mathrm{O}_{3}$ composite oxides with different $\mathrm{Mg}$ contents had been facilely fabricated by one-pot EISA strategy. The obtained materials with outstanding textural properties were directly employed as the catalysts for $\mathrm{CO}_{2}$ methanation. The incorporation of the $\mathrm{Mg}$ alkaline promotor greatly enhanced the surface basicity, which was in favor of the chemisorption and activation of $\mathrm{CO}_{2}$. As a result, their low-temperature catalytic activity and $\mathrm{CH}_{4}$ selectivity toward $\mathrm{CO}_{2}$ methanation were promoted. The "volcanoshape curve" relationship between the catalytic activity and $\mathrm{Mg}$ contents was observed. It was found that only the appropriate $\mathrm{Mg} / \mathrm{Al}$ molar ratio (5\%) could maximally promote the catalytic activity. Besides, these alkaline promoted catalysts were also provided with enhanced catalytic stability owing to the confinement effect of the mesoporous framework. The Ni active site and $\mathrm{Mg}$ basic promotor were in situ embedded among the alumina matrix by the one-pot fabrication strategy, which could effectively prevent the metallic active sites from sintering. Owing to these favorable advantages, the ordered mesoporous $\mathrm{NiO}-\mathrm{MgO}-\mathrm{Al}_{2} \mathrm{O}_{3}$ composite oxides could be considered as a series of potential catalysts for $\mathrm{CO}_{2}$ methanation reaction.

\section{Acknowledgements}

The authors sincerely acknowledge the financial support from National Natural Science Foundation of China (Grant No. 21503113, 21577065, 21503142, and 91543115), International ST Cooperation Program of China (2014DFA90780), Key Projects in the National Science \& Technology Pillar Program of Jiangsu Province (BE2014602), Natural Science Foundation of Jiangsu Province (BZ201306) and a Project Funded by the Priority Academic Program Development of Jiangsu Higher Education Institutions.

\section{References}

1 M. R. Raupach, G. Marland, P. Ciais, C. Le Quéré, J. G. Canadell, G. Klepper and C. B. Field, Proc. Natl. Acad. Sci. U. S. A., 2007, 104, 10288-10293.

2 M. Aziz, A. Jalil, S. Triwahyono and A. Ahmad, Green Chem., 2015, 17, 2647-2663.

3 C. Song, Catal. Today, 2006, 115, 2-32. 
4 P. Nema, S. Nema and P. Roy, Renewable Sustainable Energy Rev., 2012, 16, 2329-2336.

5 G. A. Meehl, W. M. Washington, W. D. Collins, J. M. Arblaster, A. Hu, L. E. Buja, W. G. Strand and H. Teng, Science, 2005, 307, 1769-1772.

6 T. Sakakura, J. C. Choi and H. Yasuda, Chem. Rev., 2007, 107, 2365-2387.

7 W. Wei and G. Jinlong, Front. Chem. Sci. Eng., 2011, 5, 2-10. 8 I. Omae, Catal. Today, 2006, 115, 33-52.

9 Q. Zhang, Y. Z. Zuo, M.-H. Han, J.-F. Wang, Y. Jin and F. Wei, Catal. Today, 2010, 150, 55-60.

10 G. Bonura, M. Cordaro, C. Cannilla, F. Arena and F. Frusteri, Appl. Catal., B, 2014, 152, 152-161.

11 R. Zhou, N. Rui, Z. Fan and C. J. Liu, Int. J. Hydrogen Energy, 2016, 41, 22017-22025.

12 S. Schiebahn, T. Grube, M. Robinius, V. Tietze, B. Kumar and D. Stolten, Int. J. Hydrogen Energy, 2015, 40, 4285-4294.

13 Y. H. P. Zhang, Int. J. Hydrogen Energy, 2010, 35, 10334-10342.

14 S. Rönsch, J. Schneider, S. Matthischke, M. Schlüter, M. Götz, J. Lefebvre, P. Prabhakaran and S. Bajohr, Fuel, 2016, 166, 276-296.

15 P. J. Lunde and F. L. Kester, Ind. Eng. Chem. Process Des. Dev., 1974, 13, 27-33.

16 J. Xu, X. Su, H. Duan, B. Hou, Q. Lin, X. Liu, X. Pan, G. Pei, H. Geng, Y. Huang and T. Zhang, J. Catal., 2016, 333, 227237.

17 S. Tada, O. J. Ochieng, R. Kikuchi, T. Haneda and H. Kameyama, Int. J. Hydrogen Energy, 2014, 39, 10090-10100.

18 C. Swalus, M. Jacquemin, C. Poleunis, P. Bertrand and P. Ruiz, Appl. Catal., B, 2012, 125, 41-50.

19 J. N. Park and E. W. McFarland, J. Catal., 2009, 266, 92-97.

20 M. A. A. Aziz, A. A. Jalil, S. Triwahyono, R. R. Mukti, Y. H. Taufiq-Yap and M. R. Sazegar, Appl. Catal., B, 2014, 147, 359-368.

21 H. H. Shin, L. Lu, Z. Yang, C. J. Kiely and S. McIntosh, ACS Catal., 2016, 6, 2811-2818.

22 M. Guo and G. Lu, React. Kinet., Mech. Catal., 2014, 113, 101113.

23 G. Zhou, T. Wu, H. Xie and X. Zheng, Int. J. Hydrogen Energy, 2013, 38, 10012-10018.

24 J. Liu, C. Li, F. Wang, S. He, H. Chen, Y. Zhao, M. Wei, D. G. Evans and X. Duan, Catal. Sci. Technol., 2013, 3, 2627-2633.

25 Q. Pan, J. Peng, S. Wang and S. Wang, Catal. Sci. Technol., 2014, 4, 502-509.

26 S. Rahmani, M. Rezaei and F. Meshkani, J. Ind. Eng. Chem., 2014, 20, 1346-1352.

27 W. Zhen, B. Li, G. Lu and J. Ma, Chem. Commun., 2015, 51, 1728-1731.

28 J. Gao, Q. Liu, F. Gu, B. Liu, Z. Zhong and F. Su, RSC Adv., 2015, 5, 22759-22776.

29 C. K. Vance and C. H. Bartholomew, Appl. Catal., 1983, 7, 169-177.

30 G. Du, S. Lim, Y. Yang, C. Wang, L. Pfefferle and G. L. Haller, J. Catal., 2007, 249, 370-379.
31 L. Xu, F. Wang, M. Chen, J. Zhang, K. Yuan, L. Wang, K. Wu, G. Xu and W. Chen, RSC Adv., 2016, 6, 28489-28499.

32 N. Perkas, G. Amirian, Z. Zhong, J. Teo, Y. Gofer and A. Gedanken, Catal. Lett., 2009, 130, 455-462.

33 M. Guo and G. Lu, Catal. Commun., 2014, 54, 55-60.

34 M. Guo and G. Lu, RSC Adv., 2014, 4, 58171-58177.

35 G. Zhi, X. Guo, Y. Wang, G. Jin and X. Guo, Catal. Commun., 2011, 16, 56-59.

36 D. L. Trimm, Catal. Today, 1999, 49, 3-10.

37 M. S. Duyar, A. Ramachandran, C. Wang and R. J. Farrauto, J. CO2 Util., 2015, 12, 27-33.

38 O. Görke, P. Pfeifer and K. Schubert, Catal. Today, 2005, 110, 132-139.

39 K. Tomishige, Y.-g. Chen and K. Fujimoto, J. Catal., 1999, 181, 91-103.

40 B. Liu and C. Au, Catal. Lett., 2003, 85, 165-170.

41 C. J. Liu, J. Ye, J. Jiang and Y. Pan, ChemCatChem, 2011, 3, 529-541.

42 F. Wang, L. Xu and W. Shi, J. CO2 Util., 2016, 16, 318-327. 43 L. Xu, H. Song and L. Chou, Appl. Catal., B, 2011, 108, 177190.

$44 \mathrm{~W}$. Shen, K. Komatsubara, T. Hagiyama, A. Yoshida and S. Naito, Chem. Commun., 2009, 6490-6492.

45 Q. Yuan, A. X. Yin, C. Luo, L. D. Sun, Y. W. Zhang, W. T. Duan, H. C. Liu and C. H. Yan, J. Am. Chem. Soc., 2008, 130, 3465-3472.

46 K. S. Sing, Pure Appl. Chem., 1985, 57, 603-619.

47 C. Li and Y. W. Chen, Thermochim. Acta, 1995, 256, 457-465.

48 D. Hu, J. Gao, Y. Ping, L. Jia, P. Gunawan, Z. Zhong, G. Xu, F. $\mathrm{Gu}$ and F. Su, Ind. Eng. Chem. Res., 2012, 51, 4875-4886.

49 M. Lenglet, A. D'Huysser, J. P. Bonelle, J. Dürr and C. K. Jørgensen, Chem. Phys. Lett., 1987, 136, 478-482.

50 L. Li, X. Wen, X. Fu, F. Wang, N. Zhao, F. Xiao, W. Wei and Y. Sun, Energy Fuels, 2010, 24, 5773-5780.

51 F. Wang, L. Xu, W. Shi, J. Zhang, K. Wu, Y. Zhao, H. Li, H. X. Li, G. Q. Xu and W. Chen, Nano Res., 2017, 10, 364-380. 52 V. García, J. J. Fernández, W. Ruíz, F. Mondragón and A. Moreno, Catal. Commun., 2009, 11, 240-246.

53 K. Y. Koo, H. S. Roh, Y. T. Seo, D. J. Seo, W. L. Yoon and S. B. Park, Appl. Catal., A, 2008, 340, 183-190.

54 R. Espinal, E. Taboada, E. Molins, R. J. Chimentao, F. Medina and J. Llorca, Appl. Catal., B, 2012, 127, 59-67.

55 D. Wang, J. Jiang, H. F. Wang and P. Hu, ACS Catal., 2015, 6, 733-741.

56 W. Luhui, S. Zhang and L. Yuan, J. Rare Earths, 2008, 26, 6670.

57 S. J. Choe, H. J. Kang, S. J. Kim, S. B. Park, D. H. Park and D. S. Huh, Bull. Korean Chem. Soc., 2005, 26, 1682-1688.

58 D. Wierzbicki, R. Debek, M. Motak, T. Grzybek, M. E. Gálvez and P. Da Costa, Catal. Commun., 2016, 83, 5-8.

59 S. Abate, K. Barbera, E. Giglio, F. Deorsola, S. Bensaid, S. Perathoner, R. Pirone and G. Centi, Ind. Eng. Chem. Res., 2016, 55, 8299-8308.

60 N. Bette, J. Thielemann, M. Schreiner and F. Mertens, ChemCatChem, 2016, 8, 2903-2906. 